SGW-39305

Revision 0

\title{
Technical Evaluation of the Interaction of Groundwater with the Columbia River at the Department of Energy Hanford Site, 100-D Area
}

Prepared for the U.S. Department of Energy

Assistant Secretary for Environmental Management

Project Hanford Management Contractor for the

U.S. Department of Energy under Contract DE-AC06-96RL13200

FLUOR.

P.O. Box 1000

Richland, Washington 


\section{Technical Evaluation of the} Interaction of Groundwater with the Columbia River at the Department of Energy Hanford Site, 100-D Area

Amec Geomatrix, Inc.

$140117^{\text {th }}$ Street, Suite 600

Denver, Colorado 80202

(303) 534-8722

Date Published

October 2008

Prepared for the U.S. Department of Energy

Assistant Secretary for Environmental Management

Project Hanford Management Contractor for the

U.S. Department of Energy under Contract DE-AC06-96RL13200

\section{FLUOR。}

P.O. Box 1000

Richland, Washington

A. A. Aasalal $\frac{11 / 0.5 / 2008}{\text { Date }}$ 
SGW-39305

Revision 0

TRADEMARK DISCLAIMER

Reference herein to any specific commercial product, process,

or service by trade name, trademark, manufacturer, or

otherwise, does not necessarily constitute or imply its

endorsement, recommendation, or favoring by the United

States Government or any agency thereof or its contractors or

subcontractors.

This report has been reproduced from the best available copy. 


\section{EXECUTIVE SUMMARY}

\section{BACKGROUND AND OBJECTIVES}

Groundwater beneath much of Hanford's 100 Areas is contaminated with hexavalent chromium $\left(\mathrm{Cr}^{+6}\right)$ as a consequence of treating reactor cooling water to prevent corrosion. $\mathrm{The}^{+{ }^{+6}}$ is thought to have infiltrated the subsurface through disposal of reactor cooling water in ponds or through spills in areas where $\mathrm{Cr}^{+6}$ solutions were mixed. Several treatment systems are in place as interim remedial actions to remove $\mathrm{Cr}^{+6}$ from the groundwater. These systems don't capture groundwater that has already passed down-gradient from or outside of the system's influence, which is the focus of this report. Some of this impacted groundwater is currently discharging to the Columbia River and some will continue to discharge in the future until sources are depleted or remediated.

$\mathrm{Cr}^{+6}$ is highly mobile and toxic to aquatic organisms, including benthic and hyporheic-zone aquatic life residing on and in the river bed, as well as salmon eggs and alevin in redds and river spawning beds. Of concern is the fate of $\mathrm{Cr}^{+6}$ as it discharges to areas within the channel of the river, because sensitive species inhabit the river and its associated transition zone. The aquatic standard for $\mathrm{Cr}^{+6}$ is $11 \mathrm{ug} / \mathrm{l}$ under the current Record of Decision (ROD) for Interim Action.

In April 2008, an expert panel of scientists was convened to provide observations and suggestions intended to improve the current understanding of groundwater-surface water interactions in the 100 Areas (primarily focusing on 100-D Area), and to identify what additional analyses or approaches may provide critical information needed to design and implement effective remediation systems that will minimize impacts to river aquatic systems. The panel was asked to evaluate the likely mechanisms that control the locations, timing, and quantity of contaminated groundwater that enters the riverbed and suggest how current data sets and interpretations and possibly new data sets and interpretations would facilitate remediation of $\mathrm{Cr}^{+6}$-impacted groundwater and reduce negative impacts to the river aquatic system. In this context, they were tasked to:

- evaluate past and current conceptual models of the interaction of local near-bank groundwater with the Columbia River;

- evaluate past and current data collection methods, data analysis techniques, assumptions, and groundwater transport and mixing mechanisms;

Evaluate the current monitoring network;

- evaluate the role played by modeling; and,

- recommend additional research to fill existing data gaps.

The expert panel's report is organized as follows:

- The Conceptual Model Framework

- Data Acquisition, Network Design, and Data Analysis

- The Role of Modeling and Current Models 
- The Role of Groundwater Surface Water Interactions in Selection of Remedial Alternatives.

In the report, the panel provides observations and suggestions that are intended to enhance understanding of how the interaction of site groundwater and the Columbia River could influence remedial technology selection, design, operation, and evaluation. The panel is aware that extensive data sets, field investigations and analyses have already been completed at the 100 Area sites and that, in some cases, the suggestions may have already been substantially addressed.

\section{THE CONCEPTUAL MODEL FRAMEWORK}

\section{Observations}

The current local and regional conceptual groundwater models assume that groundwater discharges to the Columbia River and the river functions as a hydraulic divide for local and regional groundwater flow. Local groundwater flow to the river is currently conceptualized in a two dimensional framework, with groundwater flowing from the up-gradient regional aquifer into near-river locations. The Ringold Upper Mud Unit is viewed as forming a low-permeability boundary below the unconfined aquifer.

Groundwater flow under the near-bank locations is generally assumed to be perpendicular to the river with deeper geologic formations not contributing to shallow groundwater or observed river exchanges along the river bank. The daily variability of river stage creates a complex zone of mixing within the near-bank groundwater system which is thought to be the major mechanism for reduction of $\mathrm{Cr}^{+6}$ concentrations in the near-river sediments. Springs observed on the river banks are attributed to bank storage of river water and site groundwater discharging to the river when river stage drops. Site groundwater containing $\mathrm{Cr}^{+6}$ generally discharges to the banks via springs and through the bottom of the Columbia River immediately adjacent to the Site.

\section{Suggestions}

1. The panel suggests that existing conceptual models of the local groundwater systems should be further reviewed to determine if the current interpretation of groundwater flow boundaries in a two-dimensional setting will yield the level of understanding needed to address all the important processes affecting groundwater and river exchanges with potential impact to the proposed remedial systems. The panel suggests that a three-dimensional analysis of the groundwater flow system, as well as a detailed water budget, be completed. The hydrologic and hydrogeologic complexities of the Columbia River and the near-bank locations should be carefully considered so that remedial designs can account for appropriate hydrologic interactions between the river and the groundwater. The three-dimensional analysis should include evaluation of the impacts of local-scale geologic and hydrogeologic heterogeneities.

2. As the exchange of groundwater and river water is spatially and temporally complex, approaches to identify likely in-channel groundwater discharge locations and the nature of exposure of aquatic biota to impacted groundwater should be further examined by establishing channel characteristics that correlate with the discharge of groundwater. River channel mapping and correlation with bed features and groundwater discharge should be completed. 
3. The panel suggests that the spatial extent of chromium discharge to the Columbia River should be evaluated further and correlated with the identified in-channel groundwater discharge zones. This analysis requires that the transient nature of both the river stage and local groundwater system be included in characterization of in-channel water exchanges. The mixing/dilution conceptual model for the 100-D Area, which suggests that concentrations discharging to the Columbia River will be below aquatic standards, should be evaluated in the context of a local groundwater river-exchange conceptual model. Transport, fate and remediation designs all should consider the three-dimensional localized groundwater system. At 100-D Area, the $\mathrm{Cr}^{+6}$ source investigation should be continued and expanded to examine if observed $\mathrm{Cr}^{+6}$ distributions at near-bank sites may be due to regional groundwater discharge, water from the Ringold aquitard, and/or impacted vadose-zone sediments.

4. The panel recommends that locations of potential exposure need additional definition to appropriately identify ecological exposure to $\mathrm{Cr}^{+6}$ receptors. Critical exposure pathways should be defined and targeted monitoring implemented.

\section{DATA ACQUISITION, NETWORK DESIGN AND DATA ANALYSIS}

\section{Observations}

Several aspects of hydrogeological conditions at the 100-D Area and other 100 Area sites make monitoring of water quality and flow directions difficult. Challenges include: difficult equipment installation in the subsurface and below the riverbed because of 1) geologic conditions, 2) strong vertical gradients and groundwater flow conditions, 3) rapidly changing river stage and hydraulic conditions, and 4) spatial geologic and geochemical heterogeneity.

\section{Suggestions}

1. The panel recommends that the horizontal and vertical distribution of contaminants should be determined using multi-level well installations to more completely evaluate the extent and fate of $\mathrm{Cr}^{+6}$ at near-bank locations. It would also be desirable to firmly establish how $\mathrm{Cr}^{+6}$ concentrations vary with depth at a few locations within the river channel. The transient nature of the groundwater system requires understanding of how rising and falling water tables impact contaminant concentrations in site groundwater.

2. Sampling of water seeping into the river channel is challenging. The panel suggests that the integrity of samples collected from aquifer tubes should be examined to ensure results are representative of conditions at groundwater discharge locations.

3. To further assess how and where groundwater and river water mix, the panel suggests application of other tools, such as general water quality parameters, trace elements, and natural or introduced isotopes should be assessed to support understanding of geochemical conditions within the local groundwater system.

4. The panel also suggests that simulations of the transport and fate of $\mathrm{Cr}^{+6}$ should be evaluated by accounting for the observed and likely variability of hydrogeologic parameters in the river bank and bed. Statistical descriptions of aquifer properties and geochemical data sets should be evaluated to establish the likely uncertainty in predictions. 


\section{THE ROLE OF MODELING AND CURRENT MODELS}

\section{Observations}

Groundwater modeling has played an important role in assisting researchers and managers to understand both regional and local groundwater flow and contaminant transport. Application of groundwater models at areas near the river bank have principally relied on profile twodimensional particle-tracking under steady-state and transient conditions. These approaches have revealed the complex flow patterns associated with transient river and groundwater conditions. At the 300 Area, two-dimensional reactive solute transport modeling was conducted to evaluate the response of uranium concentrations in the shallow groundwater in relationship to the adjacent river dynamics. Both solute transport and particle-tracking tools provide insight into the local groundwater conditions. It is most likely that three-dimensional representations of groundwater and river exchange timing and locations would enhance the understanding of groundwater flow and the design of remediation systems.

\section{Suggestions}

1. The panel suggests that modeling should be conducted to predict the three-dimensional groundwater flow dynamics and transport of contaminants, with inclusion of data from the opposite side of the Columbia River, within the Ringold Upper Mud, and possibly deeper sediments and bedrock.

2. Local-scale modeling should include a realistic representation of the geological and hydrological heterogeneities through the use of Transition Probability Geostatistical (TPROGS) modeling or other similar models, which could then be incorporated into threedimensional flow and transport models.

3. A full 3-D advection-dispersion modeling approach should be assessed to enable prediction of spatially and temporally varying flow and transport processes. Two-dimensional particle tracking does not provide the full picture of the transport process. More complex aquifer characteristics data, parameter estimation techniques, and uncertainty analyses using tools like a Monte Carlo approach are needed.

\section{THE ROLE OF GROUNDWATER SURFACE-WATER INTERACTIONS IN SELECTION OF REMEDIAL ALTERNATIVES}

\section{Observations}

The exchange and mixing of river water and site groundwater is conceptualized as the principal mechanism to control $\mathrm{Cr}^{+6}$ concentrations in water discharging to the river. The processes altering observed groundwater concentrations needs additional observational and simulation support. The natural attenuation of $\mathrm{Cr}^{+6}$ in the groundwater and river settings is not clearly understood and needs further resolution. To assess remediation strategies, appropriate aquatic receptors should be identified.

\section{Suggestions}

The panel suggests that USEPA protocols to evaluate natural attenuation of inorganic contaminants should be reviewed and implemented at near-river sites and within the river channel (USEPA 2007a; 2007b). Additional monitoring and sampling designed to assess exposure levels and timing may be needed. 
TABLE OF CONTENTS

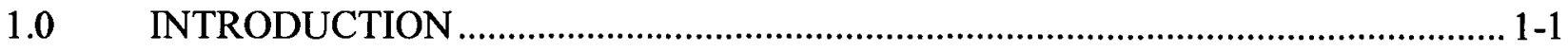

$1.1 \quad$ BACKGROUND ................................................................................ 1-1

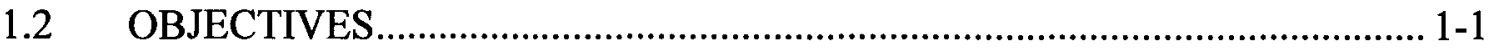

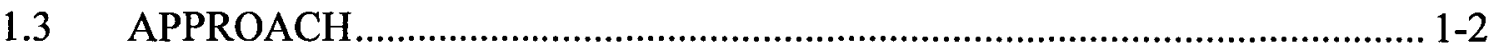

$2.0 \quad$ THE CONCEPTUAL MODEL FRAMEWORK ..................................................... 2-1

$2.1 \quad$ REGIONAL AND LOCAL SETTINGS ......................................................... 2-1

2.1.1 Potential Influence of the Columbia River on Groundwater

Flow at the 100-D Area................................................................... 2-4

2.1.2 Panel Observations and Suggestions Regarding the Local

Conceptual Model ......................................................................... 2-6

2.2 CHROMIUM DISTRIBUTION AND ATTENUATION................................ 2-7

2.2.1 Inland Chromium Distribution and Migration in the 100-D Area ...... 2-7

2.2.2 Chromium Distribution Under the River ......................................... 2-9

2.2.3 Other Factors Controlling Chromium Distribution............................2-11

2.2.4 Contaminant Attenuation Processes................................................ 2-12

3.0 DATA ACQUISITION, NETWORK DESIGN, AND DATA ANALYSIS ................ 3-1

3.1 DATA ACQUISITION METHODS AND QUALITY ……………………...... 3-1

3.1.1 Suggestions for Monitoring Well Network Design and Data

Acquisition ................................................................................. 3-1

3.2 AQUIFER TUBE WELLS AND RIVER TUBE WELLS............................... 3-2

3.2.1 Aquifer Tube and River Tube Construction and Integrity ................... 3-2

3.2.2 Source Water Quality to Identify Physical and Geochemical Processes Impacting Site and River-Bed Water Quality...................... 3-3

3.2.3 Hydraulic Gradients to Characterize Groundwater Conditions within the River Channel ................................................................... 3-4

3.2.4 Observations and Suggestions Related to Use of Hydraulic Gradients to Characterize Groundwater Conditions within the River Channel................................................................................ 3-4

3.2.5 Presentation and Interpretation of Water Quality Data........................ 3-5

3.3 MONITORING AND SAMPLING NETWORK DESIGN.............................. 3-5

4.0 Characterization of the $\mathrm{Cr}^{16}$ Distribution Beneath the Columbia River........................ 4-1

4.1.2 Determine the Role of the Ringold Upper Mud Aquitard in Contaminant Transport.

4.1.3 Characterize Vertical Contaminant Distribution in Unconsolidated Materials Adjacent to the River ................................. 4-4

4.1.4 Characterize Flow from the Opposite Bank of the River and Identify Hydraulic Divides.

4.1.5 Estimate Contaminant Transport Parameters..................................... 4-5

4.2 DATA ANALYSIS ……………......................................................... 4-6

4.2.1 Temperature Data and Pumping Tests ................................................ 4-6

4.2.2 Comments and Suggestions Regarding Data Analysis ........................ 4-7 
5.0 THE ROLE OF MODELING AND CURRENT MODELS ................................. 5-1

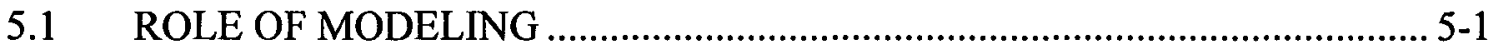

5.2 LOCAL AND REGIONAL MODELS ................................................. 5-2

5.2.1 Suggestions for Regional Modeling............................................. 5-3

5.2.2 Suggestions for Local-scale Modeling...........................................5-3

5.3 POTENTIAL USEFULNESS OF A 300-AREA TYPE MODEL ................... 5-4

5.3.1 Suggestions Regarding Numerical Experiments and

Conceptualizations

6.0 ROLE OF GROUNDWATER SURFACE WATER INTERACTIONS IN SELECTION OF REMEDIAL ALTERNATIVES. 6-1

6.1 VIABILITY OF MONITORED NATURAL ATTENUATION AS A COMPONENT OF THE REMEDIATION SYSTEM FOR 100-D AREA

6.1.1 Observations and Suggestions Regarding Monitored Natural

Attenuation 6-6

6.2 OPTIMIZING REMEDIATION

6.2.1 Suggestions Related to Optimizing Remediation

7.0 REFERENCES $7-1$

\section{APPENDICES}

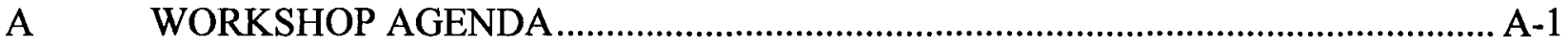

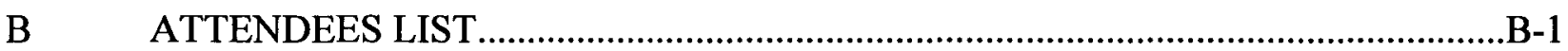

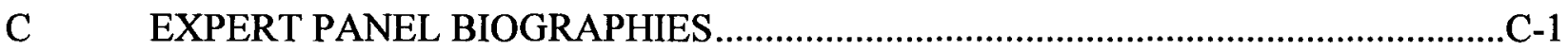

D TPROGS GEOSTATISTICAL MODELING OF HYDROFACIES ......................... D-1 


\section{Table of Figures}

Figure 2-1. Near-River Cross Section in the 100-H Area.

Figure 2-2. Potentiometric Map of the Hanford Site, (Peterson, et al. 2007, "Perspective on the Hanford Site-Columbia River Systems," presentation at the Washington Hydrogeology Symposium, Tacoma, WA, May 1-3, 2007).

Figure 2-3. Conceptual Model of Groundwater-Surface Water Interaction at the NearRiver 100 Area sites.

Figure 2-4. Potentiometric Map of the 100-D Area, ( Peterson, 2008) Geohydrology and Contamination in Hanford's 100 Areas," presentation to the GroundwaterColumbia River Interactions Technical Workshop, Richland, WA, April 16$18,2008$.

Figure 2-5. A) Three-dimensional Generalized Conceptual Model of the GroundwaterSurface Water Interaction in the 100 Areas of the Hanford Site. B) Expanded Near and Within Channel Representation.

Figure 2-6. Plan View of $\mathrm{Cr}^{+6}$ plumes in the 100-D Area (Peterson, R.E. et al., 2008, Discharge of Hanford Site Groundwater to the Columbia River System, presentation to the Groundwater-Columbia River Interactions Technical Workshop, Richland, WA, April 16-18, 2008).

Figure 2-7. Cross Section of Near-Shore Monitoring Locations Showing Chromium Concentrations in Groundwater (DOE/RL-2008-01 2008).

Figure 3-1. Schematic of Aquifer Tube and River Tube Installations

Figure 6-1. Current Conceptual Model of Groundwater and Surface Water Mixing at High RiverStage.

Figure 6-2. Conceptual Model of High River Stage that Incorporates the Effect of a Semicontinuous Armored Layer.

Figure 6-3. Conceptual Model of Low River Stage that Incorporates the Effect of Windows through the Armored Layer.

Figure 6-4. Conceptual Model of Low River Stage that Incorporates the Effect of a Scoured-out Ringold Aquitard Beneath the River. 
SGW-39305, Rev. 0

\section{TERMS}

CMT

$\mathrm{Cr}+{ }^{3}$

$\mathrm{Cr}+{ }^{6}$

DOE

DTS

EM

USEPA

GPR

ISRM

MNA

PCE

PNNL

ROD

TPROGS

USEPA

VOC

Continuous Multi-channel Tubing

Trivalent Chromium

Hexavalent Chromium

U.S. Department of Energy

Distributed Temperature Sensors

Electromagnetic

Environmental Protection Agency

Ground Penetrating Radar

In Situ Redox Manipulation

Monitored Natural Attenuation

Perchloroethylene

Pacific Northwest National Laboratory

Record of Decision

Transition Probability Geostatistical Software

United States Environmental Protection Agency

Volatile Organic Compounds 
METRIC CONVERSION CHART

\begin{tabular}{|c|c|c|c|c|c|}
\hline \multicolumn{3}{|c|}{ Into Metric Units } & \multicolumn{3}{|c|}{ Out of Metric Units } \\
\hline If you know & Multiply by & To get & If you know & Multiply by & To get \\
\hline Length & & & Length & & \\
\hline inches & 25.40 & millimeters & millimeters & 0.0394 & inches \\
\hline inches & 2.54 & centimeters & centimeters & 0.394 & inches \\
\hline feet & 0.305 & meters & meters & 3.281 & feet \\
\hline yards & 0.914 & meters & meters & 1.094 & yards \\
\hline miles (statute) & 1.609 & kilometers & kilometers & 0.621 & miles (statute) \\
\hline Area & & & Area & & \\
\hline sq. inches & 6.452 & sq. centimeters & sq. centimeters & 0.155 & sq. inches \\
\hline sq. feet & 0.0929 & sq. meters & sq. meters & 10.764 & sq. feet \\
\hline sq. yards & 0.836 & sq. meters & sq. meters & 1.196 & sq. yards \\
\hline sq. miles & 2.591 & sq. kilometers & sq. kilometers & 0.386 & sq. miles \\
\hline acres & 0.405 & hectares & hectares & 2.471 & acres \\
\hline Mass (weight) & & & Mass (weight) & & \\
\hline ounces (avoir) & 28.349 & grams & grams & 0.0353 & ounces (avoir) \\
\hline pounds & 0.454 & kilograms & kilograms & 2.205 & pounds (avoir) \\
\hline tons (short) & 0.907 & ton (metric) & ton (metric) & 1.102 & tons (short) \\
\hline Volume & & & Volume & & \\
\hline teaspoons & 5 & milliliters & milliliters & 0.034 & $\begin{array}{l}\text { ounces } \\
\text { (U.S., liquid) }\end{array}$ \\
\hline tablespoons & 15 & milliliters & liters & 2.113 & pints \\
\hline $\begin{array}{l}\text { ounces } \\
\text { (U.S., liquid) }\end{array}$ & 29.573 & milliliters & liters & 1.057 & $\begin{array}{l}\text { quarts } \\
\text { (U.S., liquid) }\end{array}$ \\
\hline cups & 0.24 & liters & liters & 0.264 & $\begin{array}{l}\text { gallons } \\
\text { (U.S., liquid) }\end{array}$ \\
\hline pints & 0.473 & liters & cubic meters & 35.315 & cubic feet \\
\hline $\begin{array}{l}\text { quarts } \\
\text { (U.S., liquid) }\end{array}$ & 0.946 & liters & cubic meters & 1.308 & cubic yards \\
\hline $\begin{array}{l}\text { gallons } \\
\text { (U.S., liquid) }\end{array}$ & 3.785 & liters & & & \\
\hline cubic feet & 0.0283 & cubic meters & & & \\
\hline cubic yards & 0.764 & cubic meters & & & \\
\hline Temperature & & & Temperature & & \\
\hline Fahrenheit & $\left({ }^{\circ} \mathrm{F}-32\right)^{* 5 / 9}$ & Centigrade & Centigrade & $\left({ }^{\circ} \mathrm{C}^{* 9 / 5}\right)^{+3} 2$ & Fahrenheit \\
\hline Radioactivity & & & Radioactivity & & \\
\hline picocurie & 37 & millibecquerel & millibecquerel & 0.027 & picocurie \\
\hline
\end{tabular}


SGW-39305, Rev. 0

This page left intentionally blank 


\subsection{INTRODUCTION}

\subsection{BACKGROUND}

Groundwater beneath much of Hanford's 100 Areas is contaminated with hexavalent chromium $\left(\mathrm{Cr}^{+6}\right)$ as a consequence of treating reactor cooling water to prevent corrosion. Several treatment systems are in place to remove $\mathrm{Cr}^{+6}$ from the groundwater; however, these systems currently do not reduce $\mathrm{Cr}^{+6}$ to concentrations below aquatic standards. Of concern is the transport of $\mathrm{Cr}^{+6}$ to areas within the channel of the river, as sensitive species inhabit the river and its associated transition zone. The aquatic standard for $\mathrm{Cr}^{+6}$ is currently $11 \mathrm{ug} / \mathrm{l}$ under the Record of Decision (ROD) for Interim Action and Department of Energy (DOE) currently plans to pursue remediation of the groundwater to achieve the $11 \mathrm{ug} / 1$ standard.

Because the compliance wells used to monitor the current remediation systems are located some distance from the river, they may not provide an accurate indication of $\mathrm{Cr}^{+6}$ concentrations in the water that reaches the riverbed. In addition, because salmon spawning areas are considered a high priority for protection from Hanford contaminants, it would be advantageous to understand 1) to what extent $\mathrm{Cr}^{+6}$ discharged to the near-shore or river ecosystems is diluted or attenuated and 2) mechanisms that could mitigate the exposure of the river ecosystems to the discharging $\mathrm{Cr}^{+6}$.

The current concentration target for $\mathrm{Cr}^{+6}$ at near-river groundwater monitoring locations is 20 $\mu \mathrm{g} / \mathrm{L}$; it is assumed that this groundwater mixes with river water that contains virtually no chromium to meet Washington Department of Ecology's (Ecology) water quality standard of 10 $\mu \mathrm{g} / \mathrm{L}$ in the river environment. This dynamic mixing process is believed to be driven by daily and seasonal changes in river stage and groundwater remediation system operations, and has been validated using analytical data from numerous groundwater samples obtained adjacent to and within the banks of the river. Although the mean mixing factor of river water and site groundwater in this zone has been estimated to be equal parts of groundwater and river water, a wide range of mixing ratios likely occurs at various times of the day and year. The degree of mixing and dilution appears to be greatly influenced by the river stage and other groundwater/surface water interaction. The extent of mixing, thus, has implications for the design and operation of the groundwater remediation systems.

Improved understanding of this "dilution" mechanism is needed to design an optimum "systems approach" to accelerate remediation of the near-shore contaminant plumes. More information on the pathway from near-river mapped plumes to riverbed receptor locations is also needed to develop a defensible proposed plan for a future ROD for final remedial action of contaminated groundwater.

\subsection{OBJECTIVES}

In April 2008, an expert panel of scientists was convened to review existing information and provide observations and suggestions to improve the current understanding of groundwatersurface water interactions in the 100 Areas (primarily focusing on 100-D Area), and to identify what additional analyses or approaches may provide critical information needed to design and implement remediation systems that will minimize impacts to river aquatic systems. Specific objectives provided to the panel included: 
- comment on approaches and methods to improve the current understanding of groundwater-surface water interactions, specifically how contaminated groundwater enters the riverbed and how this relates to remediation of chromate in the groundwater in the 100 Areas;

- evaluate past and current data collection methods, data analysis techniques, assumptions, and groundwater transport and mixing mechanisms;

- evaluate the current monitoring network (monitoring wells, aquifer tubes, and shoreline/river monitoring);

- evaluate the role played by modeling; and,

- suggest additional research to fill data gaps and perform modeling.

\subsection{APPROACH}

The project approach involved convening the expert panel at a technical workshop that was held April 16-18, 2008 in Richland WA. The panel was composed of members having significant technical experience in groundwater-surface water interactions, shallow groundwater and hyporheic-zone instrumentation and monitoring, groundwater flow modeling, geochemistry, and other related fields; their experience is drawn from academic, government, and consulting venues. Panel participants included: Dr. Brewster Conant. Jr., University of Waterloo; Dr. George Matanga, US Bureau of Reclamation; Dr. Richard Niswonger, US Geological Survey; Dr. Kerry MacQuarrie, University of New Brunswick; Dr. Sorab Panday, AMEC Geomatrix, Inc., and Dr. William Woessner, University of Montana. Dr. Dawn Kaback, AMEC Geomatrix, Inc., acted as panel facilitator and project coordinator. Dr. Robert Peterson, Pacific Northwest National Laboratory (PNNL), assisted with scoping of the workshop agenda, arranging for specific scientific material to be presented at the workshop and provided to the panel beforehand, and arranging for the field trip conducted during the workshop.

The panel's observations, comments, and suggestions are based solely upon their review of specific materials provided prior to and during the workshop. They recognize that there is significant scientific work and published reports that have been completed or are currently underway that they either have not reviewed or may not be aware of. As such, the panel's comments must be considered in the context of their limited assignment.

Those materials reviewed by the panel prior to the workshop included the following:

1. NEPA-Char_PNNL-6415R18_sec4.pdf. Section 4.4 "Hydrology" of the Hanford Site National Environmental Policy Act (NEPA) Characterization, PNNL-6415, Rev. 18, September 2007 (general overview of hydrology at the Hanford Site).

2. GW-Rept_100D_gw07_205.pdf. Section 2.5 "100-HR-3D Operable Unit" of the annual Groundwater Monitoring Report, PNNL-16346 for FY 2006 (annual report on groundwater for the 100-D Area, organized around contaminants of concern).

3. EnvRept_sec10-4_10-5.pdf. Sections 10.4 "Surface-Water and Sediment Monitoring" and 10.5 "Columbia River Shoreline Springs Monitoring" of the annual Environmental Report. PNNL-16623 for FY 2006 (describes results of river-environment monitoring activities, including riverbanks springs/sediment, and free-flowing stream water quality). 
4. ZOI_PNNL-13674.pdf. Peterson, R.E. and M.P. Connelly. 2001. Zone of Interaction between Hanford Site Groundwater and Adjacent Columbia River Channel. PNNL13674, October 2001. Pacific Northwest National Laboratory, Richland, Washington (two-dimensional flow simulation and groundwater/river water mixing; contaminant dilution).

5. RVR-Pore-100D_BHI-00778.pdf. Hope, S.J. and R.E. Peterson. 1996. Chromium in River Substrate Pore Water and Adjacent Groundwater: 100-D/DR Area, Hanford Site, Washington. BHI-00778, Rev. 0, September 1996. Prepared by CH2M HILL Hanford, Inc. for Bechtel Hanford, Inc., Richland, Washington (riverbed pore water was collected by divers and analyzed for $\mathrm{Cr}^{+6}$; evaluation of substrate for salmon spawning; discovery of major groundwater plume).

6. HyporhRept_PNNL-16805.pdf. Fritz, B.G., R.D. Mackley, N.P. Kohn, G.W. Patton, T.J. Gilmore, D.P. Mendoza, D. McFarland, A.L. Bunn, and E.V. Arntzen. 2007. Investigation of the Hyporheic Zone at the 300 Area, Hanford Site. PNNL-16805, October 2007. Pacific Northwest National Laboratory, Richland, Washington (focus on methods to characterize hydrologic aspects of zone of interaction; field work conducted at 300 Area; high frequency record of water quality and gradients).

The workshop agenda is provided in Appendix A; a list of workshop participants is provided in Appendix B. Biographies of the expert panel members are provided in Appendix C.

During the first two days of the workshop, technical presentations on site geology, hydrology, historical operations, 100 Area contaminant plumes, groundwater/river water interactions, Columbia River substrate habitat, field monitoring, and the River Corridor Baseline Risk Assessment, were given by staff from Fluor Hanford, PNNL, and Washington Closure Hanford. Regulatory perspectives were provided by Washington Department of Ecology and the Environmental Protection Agency. The remainder of the workshop involved internal panel discussions and an out-briefing at the conclusion of the workshop. After the workshop, the panel prepared this report to document their observations and suggestions.

Section 1 of the report provides introductory information, such as background, goal/objectives of the project, and approach. Section 2 discusses the conceptual model framework, as well as chromium distribution and attenuation; Section 3 evaluates data acquisition, network design, and data analysis; Section 4 provides an evaluation of the role of modeling and current models; and, Section 5 describes the role of groundwater surface-water interactions in the selection of remedial alternatives. 
SGW-39305, Rev. 0

This page left intentionally blank 


\subsection{THE CONCEPTUAL MODEL FRAMEWORK}

\subsection{REGIONAL AND LOCAL SETTINGS}

It is assumed that the regional geologic framework and broad-scale hydrologic conditions that recharge, move, store, and discharge groundwater to the Columbia River system are sufficiently described by previous and current research to provide a basic framework for the development of appropriately bounded local-scale, near-river hydrologic models (Figure 2-1). These individual plume-scale conceptual models are needed to support the design and operation of effective groundwater remediation systems.

Figure 2-1. Near-River Cross Section in the 100-H Area

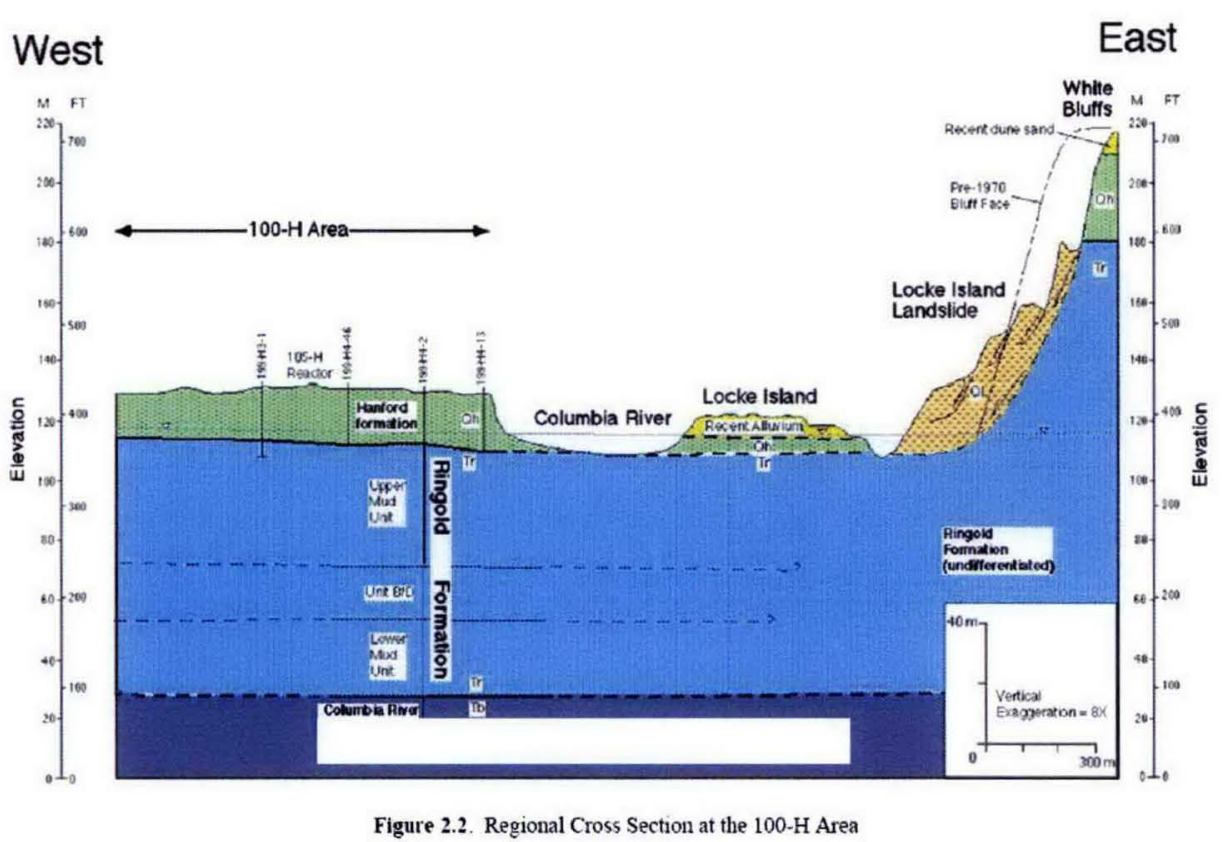

Conceptually, upland groundwater flow within the near-surface Hanford and Ringold Formations is generally towards the Columbia River, enters river bank sites and discharges to the river (Figure 2-2). As local-scale conceptual models to support design and performance evaluation of remediation systems are developed, additional analyses of the three-dimensional extent of regional groundwater movement within and beneath these areas and the distribution of discharge to the Columbia River may require further evaluation. Likely, additional investigations of the local groundwater systems will require a clear understanding of how local geologic conditions and groundwater divides associated with the river are distributed within and near the river (Figure 2-2). 
Figure 2-2. Potentiometric Map of the Hanford Site, (Peterson, et al. 2007, "Perspective on the Hanford Site-Columbia River Systems," presentation at the Washington Hydrogeology Symposium,Tacoma,WA, May 1-3, 2007).

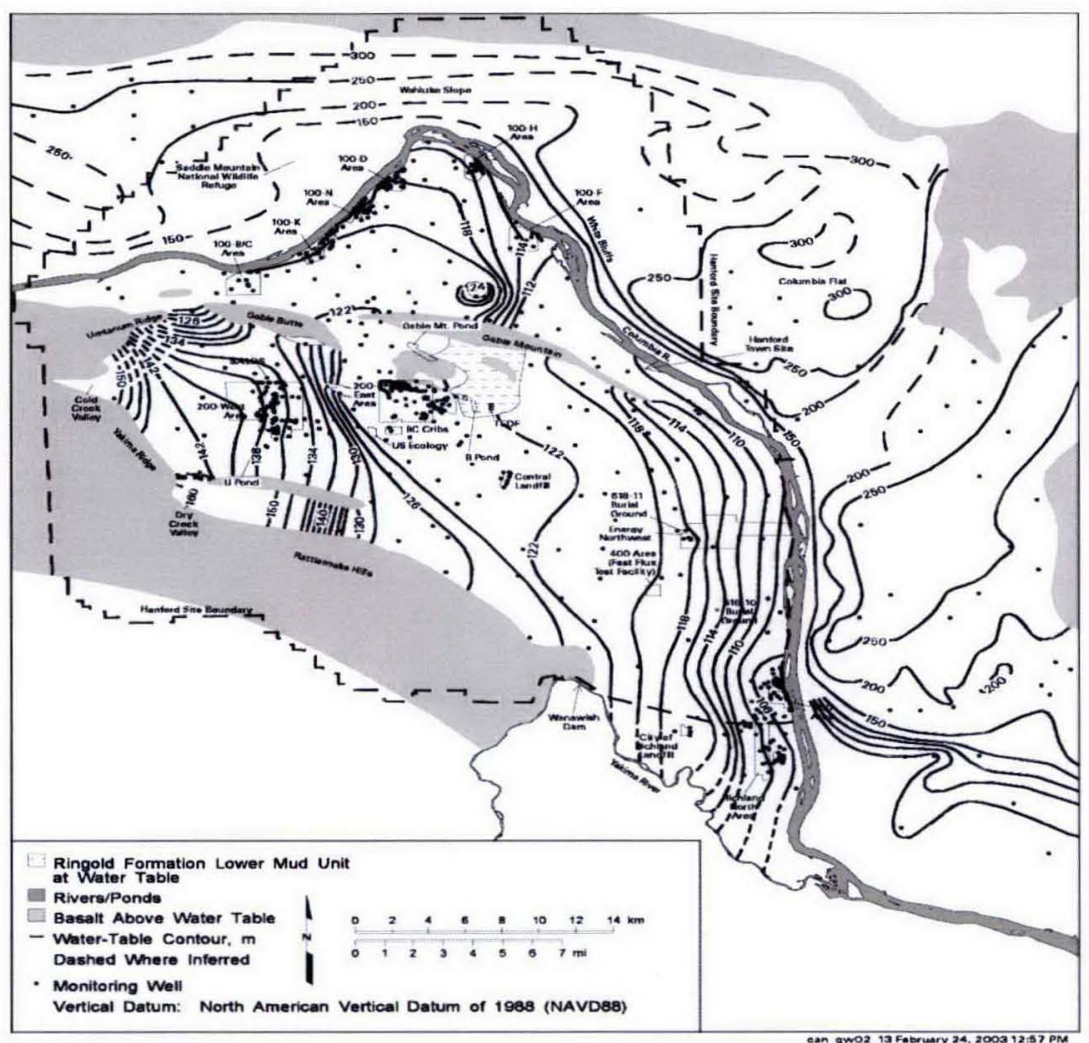

At river-bank sites like the 100-D Area, shallow groundwater flow is conceptualized to occur principally within the Hanford or Ringold Formations bounded vertically by the underlying Ringold aquitard in the Ringold Upper Mud Unit and by a hydrologic divide associated with the Columbia River (Figure 2-3). Local groundwater flow to the river is currently conceptualized two-dimensionally with groundwater flowing into the area from the up-gradient regional aquifer located to the south (Figure 2-3 and 2-4). These near-river groundwater systems are highly dynamic, influenced by regional groundwater conditions, local site remediation efforts, and the daily and seasonal variations of river stage. 
Figure 2-3. Conceptual Model of Groundwater-Surface Water Interaction at the Near-River 100 Area sites.

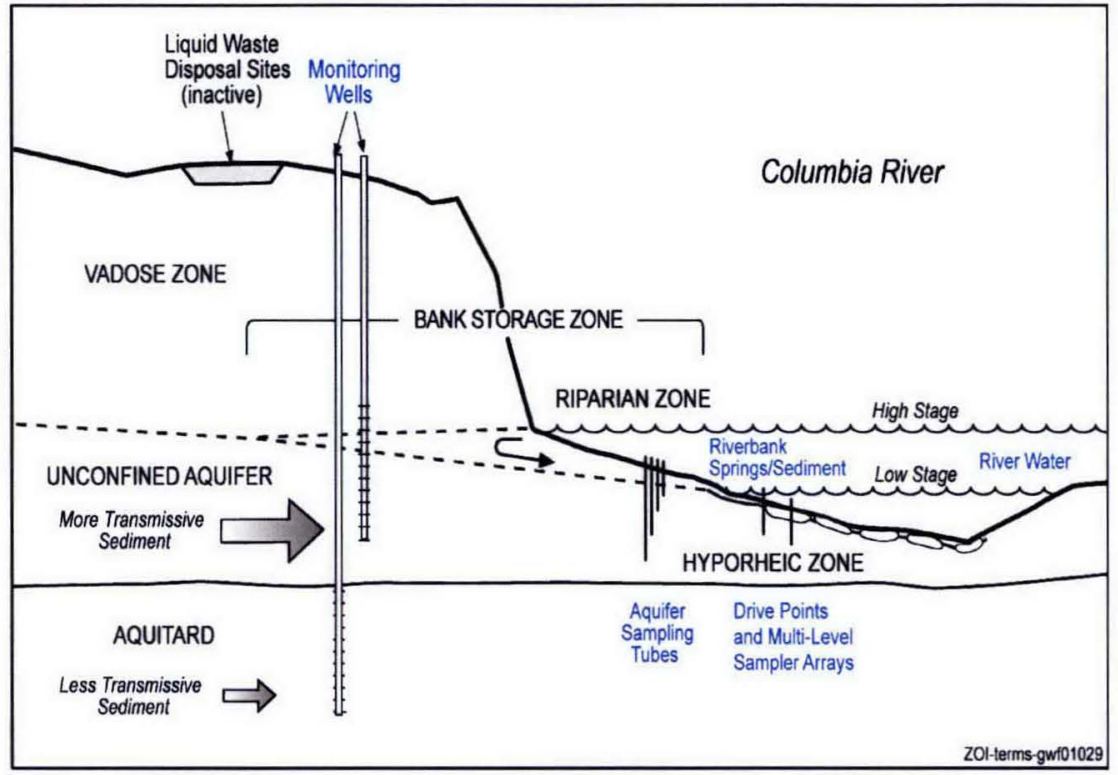

Figure 2-4. Potentiometric Map of the 100-D Area, ( Peterson, 2008) Geohydrology and Contamination in Hanford's 100 Areas," presentation to the Groundwater-Columbia River Interactions Technical Workshop, Richland, WA, April 16-18, 2008.

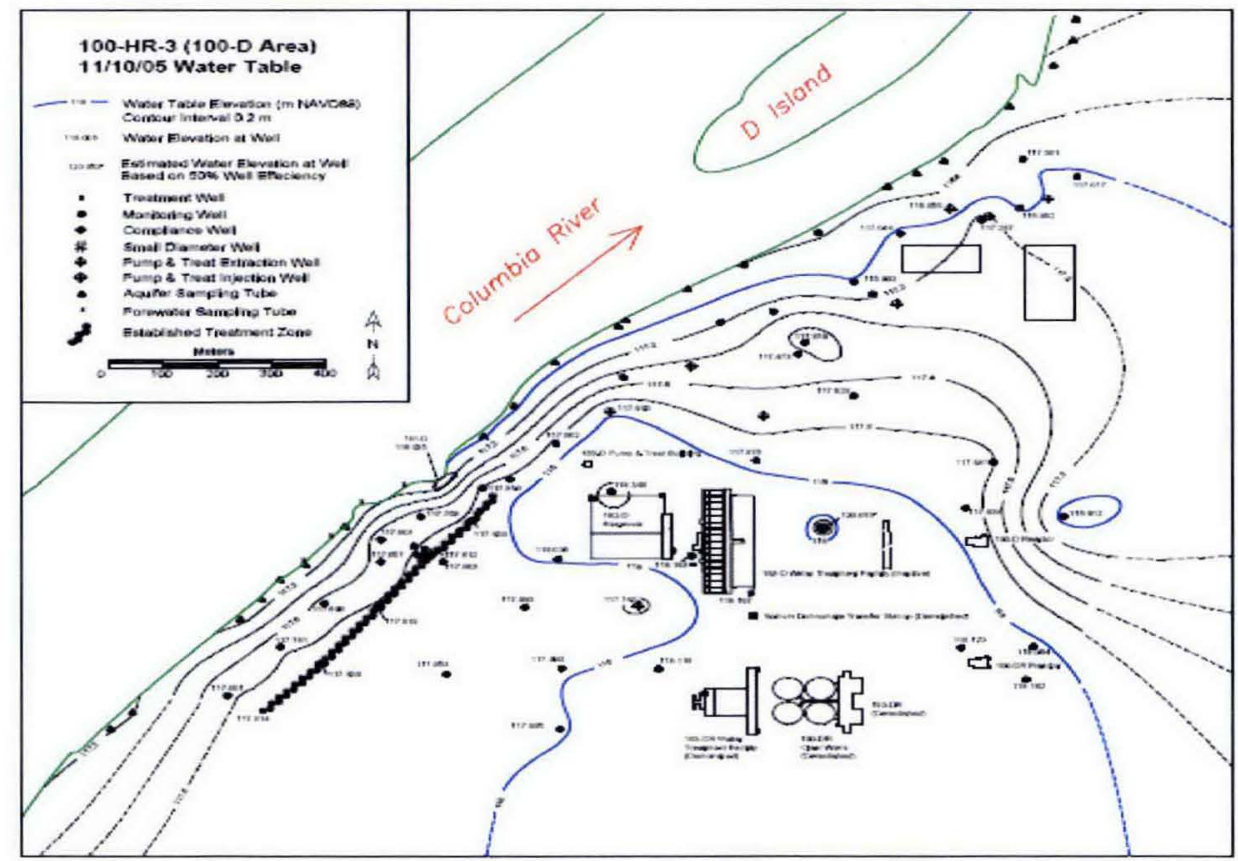


The main features of the current conceptual model are:

- Flow under the site and near the banks is generally assumed to be predominantly perpendicular to the potentiometric contours of the groundwater as it discharges into the river.

- Deeper geologic formations are assumed not to contribute significantly to shallow groundwater or observed river exchanges along the river bank.

- The daily variability of river stage creates a complex zone of mixing within the near-bank groundwater system.

- Some of the springs observed on the river banks are attributed to bank storage of river water and site groundwater discharging to the river when river stage drops.

- Site groundwater generally discharges to the banks via springs and through the bottom of the Columbia River immediately adjacent to the Site.

\subsubsection{Potential Influence of the Columbia River on Groundwater Flow at the 100- D Area}

As described above, the existing conceptual model of the groundwater-river interaction is basically two-dimensional. The Columbia River is conceptualized to form a two-dimensional boundary to the near-river groundwater flow system. However, the interaction is likely more complex than currently conceptualized. As a result, as groundwater remediation is planned, the site conceptual model will need to be revised based upon a three-dimensional conceptual framework.

Based on our limited review of site data and our knowledge of river systems, specifically how groundwater is likely exchanged and interfaced between the river channel and near- channel area, the panel created a generalized three-dimensional conceptual model for the river/groundwater exchange process (Figure 2-5A and 2-5B). It is fully recognized that groundwater exchange with and within a river as large as the Columbia River is difficult to evaluate and thus, key components and associated uncertainties that may impact remediation designs will need to be identified and evaluated. 
Figure 2-5. A) Three-dimensional Generalized Conceptual Model of the Groundwater-Surface Water Interaction in the 100 Areas of the Hanford Site. B) Expanded Near and Within Channel Representation.

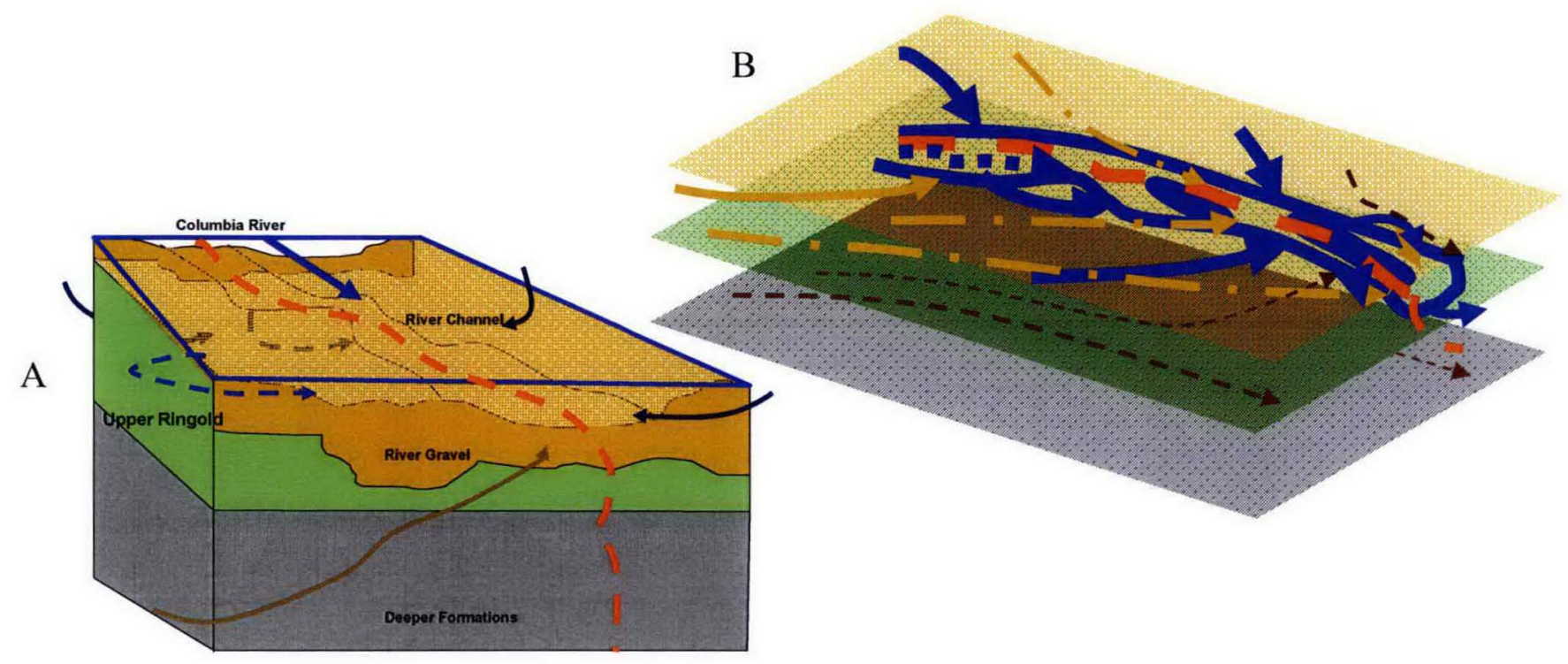

A description of the graphical representation in Figure 2-5 follows.

- Blue solid lines outline the Columbia River with the river flow from left to right.

- Dark blue arrows represent the shallow Hanford and Upper Ringold groundwater flow south of the river and flow in the Ringold and other formations north of the river (unit 1 brown). The relative contribution of flows from south and north of the river will have an impact on the lateral position of the hydraulic divide.

- Groundwater flow in the underlying Ringold (unit 2 green) and basalt bedrock (unit 3 gray) is represented by orange and brown arrows. It is currently unclear what significance, if any, these flows may have on contaminated groundwater discharge.

- The surface location of the hydrogeologic divide is represented using a red dashed line. This divide may actually have a complex geometry in the subsurface.

- The blue arrow at the right side of Figure 2-5B extending from the river channel bottom and pointing downstream represents hyporheic exchange.

This generalized representation suggests that groundwater exchange along the banks and bed of the Columbia River can be spatially complex and that groundwater conditions, river-channel configuration, and regional groundwater system boundary conditions influence hyporheic exchange and the near-bank three-dimensional groundwater river interactions. These processes are driven by differences in water table and river elevations, and, as recognized by current observations, conditions that change temporally. For example, a daily $3-\mathrm{m}$ change in river levels superimposed with seasonal changes or alterations of site groundwater flows by remediation efforts likely causes seasonal shifts in the regional groundwater flow system that will consequently impact groundwater surface-water exchange locations and rates. 
Thus, complex geologic setting, aquifer heterogeneity, and transient nature of the surface water and groundwater result in a complex groundwater flow system. During major spring discharge events, river water may enter the banks and the adjacent groundwater system upstream of the Site and move laterally parallel to the river for some distance before discharging back into the river.

\subsubsection{Panel Observations and Suggestions Regarding the Local Conceptual Model}

The panel makes the following observations and suggestions with regard to the local conceptual model.

1. The panel suggests that the local-scale conceptual hydrogeologic model be refined with incorporation of a detailed water budget to account for the groundwater entering and exiting the site with special attention paid to quantifying the contribution of water from the river and identifying the mechanisms allowing site water to discharge to the river, recharge sources, and changes in groundwater storage. The site water budget should be examined within steady-state and multiple transient contexts. A critical part of developing the water budget will require refinement of hydrogeologic boundaries, hydrogeologic property values and distributions, and groundwater flow paths. The refined model needs to recognize the complex three-dimensional nature of groundwater flow and river/groundwater exchange to more appropriately frame conditions at riverside sites. This may require further field characterization and data analysis to improve the current understanding of the hydrogeologic system. Potential topics of investigation may include the hydrologic boundary (i.e., the river divide), the role of large-scale heterogeneity, the character of the bedrock boundary, and the influence of lateral underflow. Geophysical methods should be considered for mapping of near-shore or river deposits. Existing bathymetric data should be examined in relation to projected locations of groundwater discharge in the current conceptual model.

2. The influence of local-scale geological heterogeneities, which can range over five orders of magnitude, Groundwater (Freeze and Cherry, 1979), on groundwater flow and exchanges should be evaluated and incorporated into both conceptual and numerical models. Preferential flow has been observed during hydraulic testing and water quality sampling of the hyporheic zone (PNNL 16623, 2006). A graded or phased approach to further assessment first using data from existing drillers' logs, surface and or borehole geophysical data, and hydraulic testing should be performed to examine how local site complexity may influence flow, migration, and remediation of contaminants. Numerical extrapolation methods can be used to further analyze the effects of heterogeneity on the system. One approach to account for heterogeneity uses hydrofacies transition probability-based modeling, "TPROGS - Transition Probability Geostatistical Software, Version 2.1, User Manual," (Carle 1999). See Appendix D for more information. Other similar statistical methods could also be used.

3. The panel suggests that the in-channel discharge points and the exchange process should be further evaluated by selecting representative sites where groundwater discharge is observed or anticipated. Riverbed data such as grain size, presence/absence of armoring, hydraulic properties, and spatial distributions of these 
characteristics should be analyzed in concert with the nature of the bed and bar topography.

4. The panel suggests that further evaluation of existing or newly collected data is required to capture the complex transient nature of the hydrogeologic flow and transport system, especially the exchange with the river, and how these factors influence contaminant transport and likely exposure of river biota to contaminants of concern.

5. The local-scale site conceptual model needs to consider how possible contaminant sources and changes in groundwater flow (regional) up-gradient of the local site may alter the behavior and/or exchange of contaminants with the river system

\subsection{CHROMIUM DISTRIBUTION AND ATTENUATION}

Impacts to groundwater quality at local 100-Area sites are traced to the historical operations at the site. Contaminant sources include on-site production-related releases of river water that was treated with chromium, cycled through a reactor, cooled, and then either discharged directly to the river or allowed to seep from ponds into the subsurface and ultimately to the unconfined aquifer

Dissolved hexavalent chromium $\left(\mathrm{Cr}^{+6}\right)$ is the primary groundwater contaminant of concern in the 100-D Area; however, nitrate, sulfate, and tritium are also present in elevated concentrations in groundwater. In oxic waters, $\mathrm{Cr}^{+6}$ will exist predominantly as chromate, an anionic species (i.e., $\mathrm{CrO}_{4}{ }^{-2}$ ). In addition to hydrodynamic dispersion (mixing), the natural attenuation of $\mathrm{Cr}^{+6}$ may occur by reduction to $\mathrm{Cr}^{+3}$, which can subsequently form insoluble oxide phases or cationic species that adsorb to oxide phases, "Geochemical Reduction of Hexavalent Chromium in the Trinity Sand Aquifer," (Henderson, et al. 1994); "Vertical Distribution and Partitioning of Chromium in a Glaciofluvial Aquifer," (Nikolaidis et al. 1994).

\subsubsection{Inland Chromium Distribution and Migration in the 100-D Area}

The migration of $\mathrm{Cr}^{+6}$ toward the Columbia River occurs within plumes that originate at some distance from the river; the impact of remediation activities on the plume source areas and the persistence of the plumes outside areas of active remediation are important for assessing the duration of exposure. The existing $\mathrm{Cr}^{+6}$ plumes in the 100-D Area have been described in recent monitoring reports, e.g., DOE/RL-2008-01, 2008, Hanford Site Groundwater Monitoring for Fiscal Year 2007 and maximum plume concentrations currently exceed $1000 \mu \mathrm{g} / \mathrm{L}$ (Figure 2-6). $\mathrm{The}^{+{ }^{+6}}$ distribution is characterized by two areas of high concentrations, which may have been separated in the past by infiltration of clean water from the 182-D Reservoir near the center of the site. Dissolved chromium has consistently been detected in river-bank seepage and "aquifer tubes," which are small-diameter piezometers installed in near-shore sediments for monitoring. Dissolved $\mathrm{Cr}^{+6}$ from the 100-D Area is migrating to the east and has reached the 100-H Area. 
Figure 2-6. Plan View of $\mathrm{Cr}^{+6}$ plumes in the 100-D Area (Peterson, R.E. et al., 2008, Discharge of Hanford Site Groundwater to the Columbia River System, presentation to the GroundwaterColumbia River Interactions Technical Workshop, Richland, WA, April 16-18, 2008).

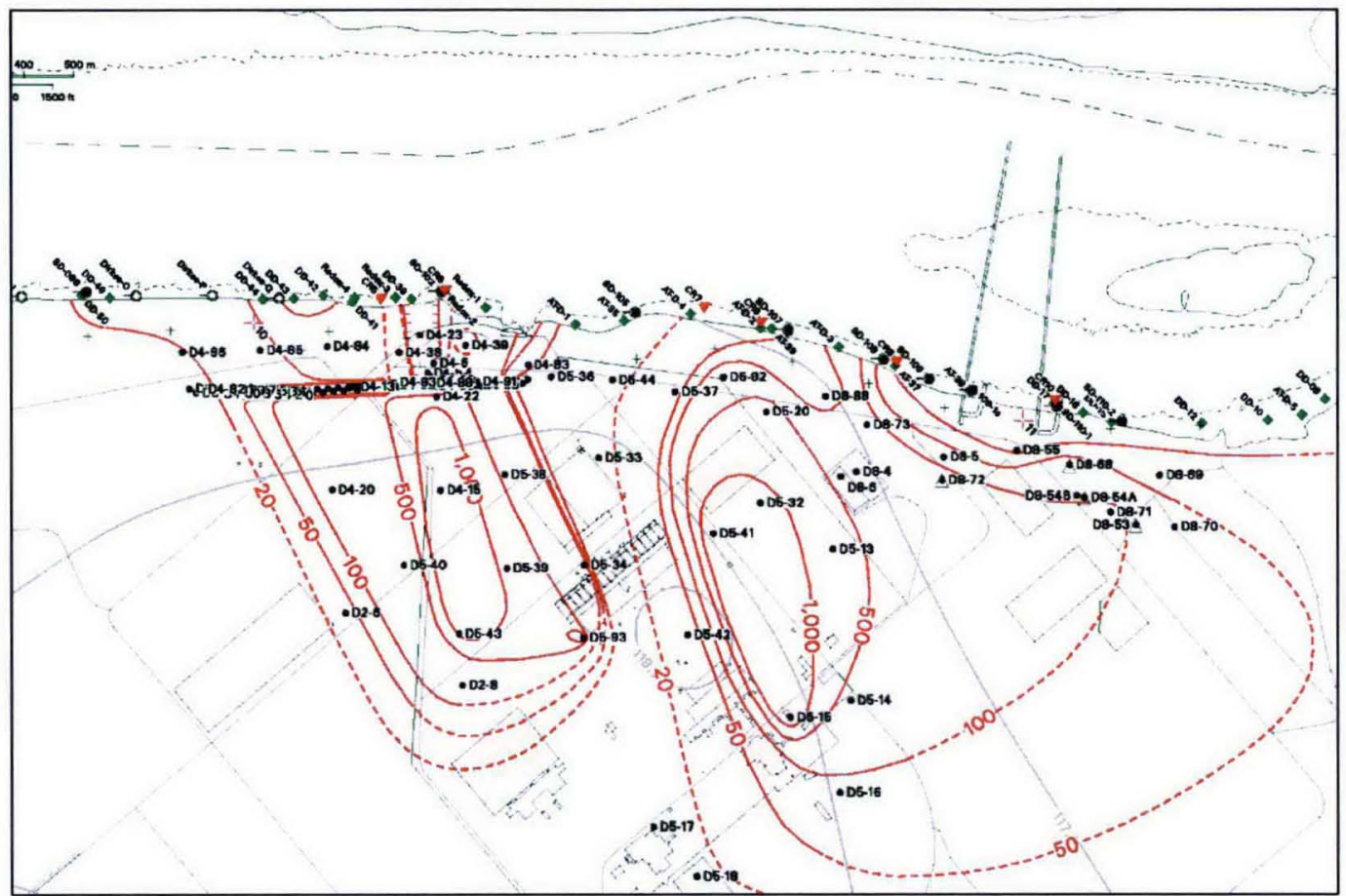

Since 1992, an estimated $450 \mathrm{~kg}_{\text {of }} \mathrm{Cr}^{+6}$ has been extracted from the northernmost 100-D Area plume (right plume in Figure 2-6) by several pump-and-treat systems, DOE/RL-2008-01 (2008). However, the dissolved chromium plumes have not decreased appreciably in size. Several possibilities to explain their continued persistence during active extraction by the pump and treat system have been identified. These include a continuing source of chromium in the vadose zone, DOE/RL-2008-01 (2008), migration of chromium from further inland toward the river, the release of chromium from the saturated aquifer sediments, or upward migration of chromium from the Ringold aquitard below the unconfined aquifer. To date, the main focus has been to identify sources in the vadose zone that are associated with past operations in the 100-D Area. While this is certainly a logical and worthwhile line of investigation, the panel considers that the other potential 'sources' may warrant consideration; these sources are discussed below.

The historical hydraulic head distribution in the area was dominated by water table mounds caused by infiltrating water from beneath the 100-D Area retention basins. This mounding may have accelerated the migration of chromium toward the east across the "horn," and may have also caused flow and transport away from the river (i.e. inland toward the southeast). If this did occur, the contaminated water may be slowly migrating back towards the river after dissipation of the mounds. Currently, the southeast extent of the 100-D Area plumes is only sparsely characterized, making it difficult to determine if there is a source of contaminated groundwater from that area. However, if that source were to be present, it would not likely have generated the currently high chromium concentrations that exist in the 100-D Area. 
Although $\mathrm{Cr}^{+6}$ is relatively mobile in oxic, near-neutral $\mathrm{pH}$ conditions, several studies have documented partitioning onto aquifer solids. For example, Henderson (1994), found an average partitioning coefficient of $0.3 \mathrm{~mL} / \mathrm{g}$ for oxidizing and near-neutral $\mathrm{pH}$ conditions in Trinity Sand sediments. If this value is used with typical porosity and bulk density values for unconsolidated sediments, it would imply that the total mass in a chromium-contaminated aquifer would be approximately three times the mass in solution. Nikolaidis et al. (1994) have found even more significant partitioning of chromium in a glaciofluvial aquifer in which dissolved oxygen ranged between 2 and $8 \mathrm{mg} / \mathrm{L}$, and $\mathrm{pH}$ was between 3 and 5.5. Their calculations indicated that $99 \%$ of the chromium located below the water table was bound to the aquifer solids, and that kinetic or diffusive-transport processes may limit the effectiveness of pump-and-treat remediation. Recent column experiments conducted with 100 Area vadose-zone sediments reveal that, despite rapid flushing of $\mathrm{Cr}^{+6}$ in the first pore volume, aqueous concentrations can persist at greater than 100 $\mu \mathrm{g} / \mathrm{L}$ for many tens of pore volumes, PNNL-17674, Geochemical Characterization of Chromate Contamination in the 100 Area Vadose Zone at the Hanford Site (Dresel et al, 2008)

Given past hydraulic conditions, such as a groundwater mound created by leaking cooling water, and the long time that chromium has been in the groundwater of the 100-D Area, chromium may have migrated into the underlying aquitard by advective and/or diffusive transport. If redox conditions were reducing in this unit, then $\mathrm{Cr}^{+6}$ may have been reduced to $\mathrm{Cr}^{+3}$, and effectively attenuated. However, this unit may also act as a continuing source of low concentrations of chromium to the shallower Ringold sands, if $\mathrm{Cr}^{+6}$ persisted, because of insufficient reduction capacity within this finer-grained unit. Currently only one well monitors a silty sand unit within the Ringold aquitard in the 100-D Area. Well 199-D8-54B, located in the northern 100-D Area, typically has chromium concentrations $<10 \mu \mathrm{g} / \mathrm{L}$, while an adjacent water-table well has concentrations above the drinking water standard, DOE/RL-2008-01 (2008).

\subsubsection{Suggestions Related to Chromium Near the River}

1. The chromium groundwater plumes located in the 100-D Area inland from the Columbia River have persisted despite the last decade of active remediation in the 100-D Area. This continued persistence is likely related to source(s) of chromium that have yet to be clearly identified, although recent drilling ( 7 boreholes) has identified concentrations in the groundwater as high as $40,000 \mathrm{ug} / \mathrm{L}$ in one well. Identification of the source(s) may enable localized source-zone remediation, which should improve conditions related to migration of contaminants toward the Columbia River.

2. The panel recommends that future assessments of remediation alternatives in the 100-D Area, such as the Remedial Process Optimization, should incorporate the results of the recent chromium geochemistry study by Dresel et al (2008). In particular, the extended tailing of chromium at concentrations exceeding $100 \mu \mathrm{g} / \mathrm{L}$ may need to be accounted for in remedial design and local-scale modeling.

\subsubsection{Chromium Distribution Under the River}

The chromium distribution along the south shoreline of the Columbia River has been characterized by regular sampling from a series of seeps, river shore and bank aquifer tubes, and in some cases, multi-level monitoring wells. The chromium data from these locations typically indicate the presence of the up-gradient (inland) contaminant plumes discussed above, although 
concentrations are significantly reduced compared to the inland values (Figure 2-7). Chromium concentrations greater than $100 \mu \mathrm{g} / \mathrm{L}$ have been detected at depths typically greater than 5 meters below land surface near the shoreline. The shallowest sampling points generally have a lower concentration than do the deeper tubes and this contrast has been attributed to mixing with river water, DOE/RL-2008-01 (2008).

Figure 2-7. Cross Section of Near-Shore Monitoring Locations Showing Chromium Concentrations in Groundwater (DOE/RL-2008-01 2008)

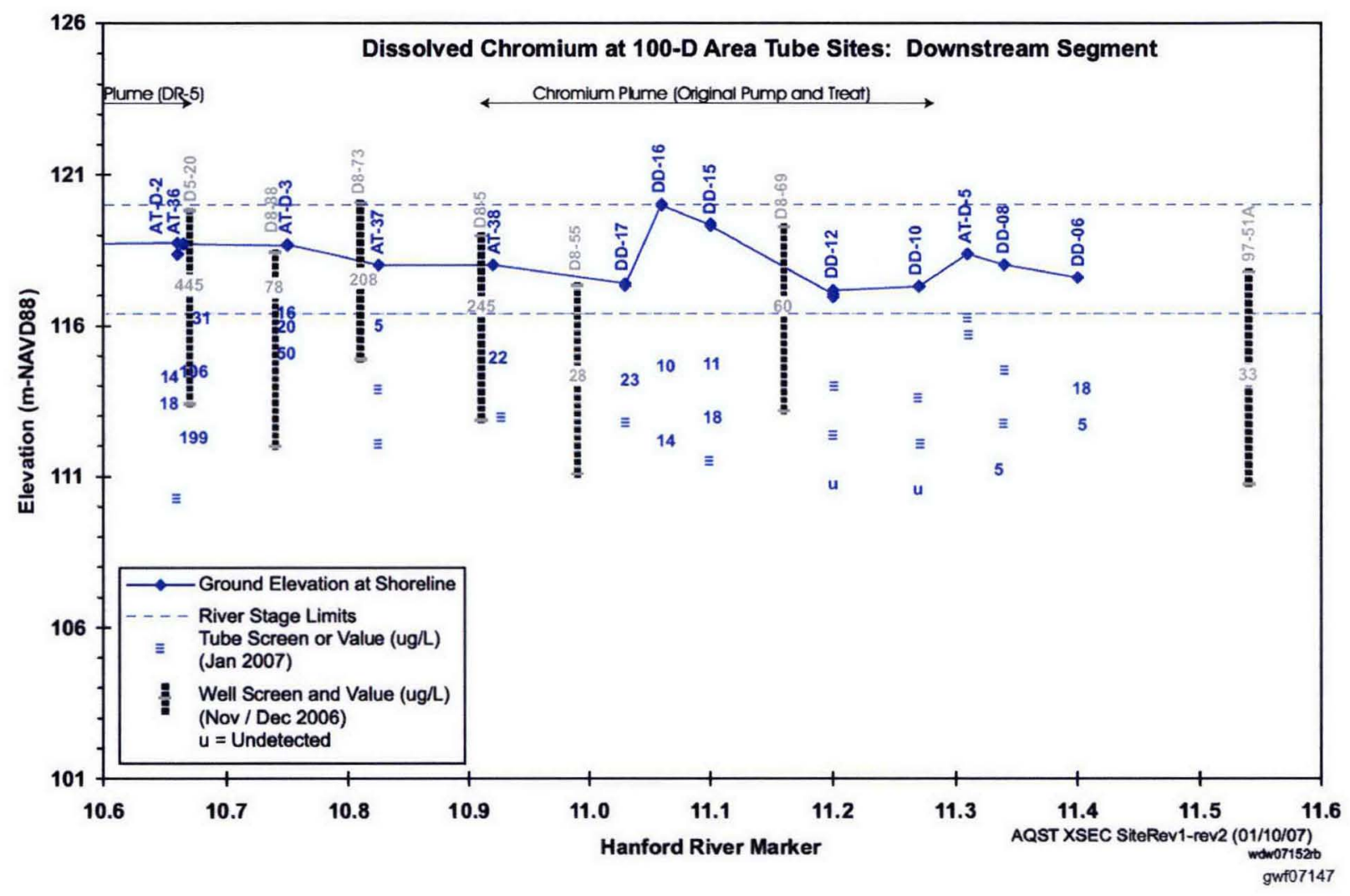

In 1995, contaminant data were also collected from beneath the river bed, at depths ranging from about 20 to $45 \mathrm{~cm}, \mathrm{BHI}-00778,1995$, Chromium in River Substrate Pore Water and Adjacent Groundwater: 100-D/DR Area. Chromium was detected at 41 of the 100 below-river sampling locations. Although this type of sampling campaign is a major undertaking, the panel considers that the data obtained are very valuable for determining exposure to chromium-contaminated waters. Before considering repeating such sampling, it would be beneficial to identify locations of preferential groundwater discharge into the river by employing other methods (e.g. geophysical techniques as discussed in Section 3.3.1). This would focus the sampling to areas that are linked hydro geologically to the contaminated on-shore groundwater. 


\subsubsection{Observations and Suggestions Regarding Chromium Concentrations Below the River Channel}

1. The panel suggests that mapping of river bed characteristics and topography would provide a template within which to target river bed geochemical sampling. Geophysical mapping of the river sediments may prove useful. Water quality sampling of bed sediment water should be guided by physical characteristics of the river-bed sediments and by the location of potential receptors (e.g. spawning locations). Ideally, sampling would be conducted at a number of the high-chromium locations that were also sampled in 1995, so that temporal comparisons can be made. At this time, it is not possible to specify desirable locations, or the number of sites that require sampling, because these will depend on the resources available, and other factors, such as public safety and environmental protection. However, data of this type may be very valuable for guiding performance monitoring during future remedial activities.

2. The design and installation of remote retrievable samplers and/or sensors that could be installed at a few selected locations to examine the transient nature of exposure of biota to the contaminants of concern may be beneficial for pre- and active-remedial monitoring.

\subsubsection{Other Factors Controlling Chromium Distribution}

Chromium in the groundwater at the 100-D Area is influenced by pump-and-treat systems and an in situ redox manipulation (ISRM) system DOE/RL-2008-01 (2008). Chromium coexists with elevated concentrations of nitrate and sulfate, which may influence chromium speciation. Because $\mathrm{Cr}^{+6}$, nitrate, and sulfate can all be reduced by organic matter, there is competition among these contaminants for electron demand (reducing capacity). Nitrate and $\mathrm{Cr}^{+6}$ can also be reduced by ferrous iron, which is the basis of the ISRM technology, "Attenuation of a Mixed Chromium and Chlorinated Ethene Ground Water Plume in Estuarine Influenced Glaciated Sediments," (Hellerich et al. 2003). A preliminary calculation using typical concentrations from the 100-D Area plumes for these three species indicates that greater than $99 \%$ of the electron demand would result from nitrate and sulfate reduction. It is unclear, therefore, how important chromium reduction might be, if for example, contaminated groundwater encountered sediments containing organic matter (e.g. near-shore soils, or Ringold clays). Further insight on chromium fate may be gained from investigating correlations among chromium, nitrate, and sulfate, and the potential for the occurrence of denitrification or sulfate reduction in the near-shore environment.

\subsubsection{Comments and Suggestions Regarding Other Factors Controlling Contaminant Distribution}

The panel suggests that historical groundwater quality data be reviewed to examine correlations among aqueous chromium, nitrate, and sulfate. Nitrate concentrations and nitrogen and oxygen isotope ratios could also be examined near locations having relatively high organic matter to determine if denitrification may be occurring. The presence of denitrification may suggest that chromium reduction is also occurring, which would provide an additional mechanism (in additional to active remediation) for reducing aqueous $\mathrm{Cr}^{+6}$ concentrations. 


\subsubsection{Contaminant Attenuation Processes}

The primary conceptual model that has been proposed for $\mathrm{Cr}^{+6}$ attenuation is mixing with river water, which is believed to occur due to dynamic bank storage processes and hyporheic zone mixing, prior to groundwater discharge to the river. This model has been applied to explore the magnitude of reoxygenation of groundwater passing the ISRM barrier in the 100-D Area (Williams et al, 1999, Anoxic Plume Attenuation in a Fluctuating Water Table System: Impact of 100-D Area In Situ Redox Manipulation on Downgradient Dissolved Oxygen Concentrations) and to better understand exposure concentrations in the 100-H Area (Peterson and Connelly, 2001). More recently, it was expanded to simulate reactive transport of uranium in the 300 Area (Yabusaki et al., 2008, Reactive transport in a Dynamic Vadose Zone-Aquifer River System, presentation to the Groundwater-Columbia River Interactions Technical Workshop, Richland, Washington, April 16-18, 2008). In the basic attenuation model, the interaction with river water produces a purely diluting effect on $\mathrm{Cr}^{+6}$ concentrations; however, the potential for chromium speciation to be altered during groundwater-surface water exchange has not been evaluated. As noted by others Nikolaidis et al. (1994), spatial variations in $\mathrm{pH}$, redox conditions and geochemistry should also be assessed to evaluate $\mathrm{Cr}^{+6}$ attenuation.

In the current conceptual model of the 100-D Area, the saturated aquifer is relatively thin (approximately 5 to $6 \mathrm{~m}$, if the Ringold aquitard is taken as a groundwater flow boundary) and is therefore similar to the 100-H Area, which was selected for flow and particle tracking modeling. However, groundwater-surface water interaction and its influence on $\mathrm{Cr}^{+6}$ occurrence and attenuation needs to be more clearly understood. The sources of chromium contributing to the observed impacted river shoreline groundwater need clarification (role of on-site sources, upgradient sources, and the likelihood of possible site-impacted cooling water that penetrated deeper, fine-grained sediments contributing to the chromium source). Understanding of the near-shore processes contributing to the observed distribution of $\mathrm{Cr}^{+6}$ also needs refinement. For example, does the influx of river water in the near-shore area displace contaminated groundwater deeper into the aquifer allowing it to discharge further from shore, and if so, what is the degree of hydrodynamic dispersion that can occur during the cyclic exchange of river water? Another unknown, which has been discussed in Section 2.1.1, is the three-dimensional aspect of dispersion and groundwater discharge that cannot be evaluated in the two-dimensional models that have been applied to date.

\subsubsection{Suggestions Related to Contaminant Attenuation Processes}

Numerical simulation of chromium transport and interaction with waters of the Columbia River should be undertaken for the 100-D Area plumes. These studies may start with relatively simple two-dimensional models, using, for example, the homogeneous flow and transport parameters selected by Williams et al (1999). The long-term objective should be to quantitatively assess chromium transport in three dimensions, and to evaluate attenuation due to river-water mixing and changes in chromium speciation. Such modeling may also need to consider competing electron demand from species such as nitrate and sulfate. Comparisons of model results with historical and current distributions of chromium or other contaminants should also be conducted. 


\subsection{DATA ACQUISITION, NETWORK DESIGN, AND DATA} ANALYSIS

\subsection{DATA ACQUISITION METHODS AND QUALITY}

The scientists attempting to characterize hydrogeologic conditions at the 100-D Area and within the Columbia River have applied both traditional and new and innovative methods. Several aspects of the hydrogeological conditions at the 100-D Area make monitoring of water quality and groundwater flow directions difficult. Field conditions represent real and practical constraints with respect to installing instrumentation and performing monitoring. The following is a brief description of some of the main challenges.

1. Geological materials are dominated by cobbles and boulders that make installation of wells and streambed monitoring equipment difficult.

2. Monitoring well construction is expensive and requires drilling through a thick coarse grained vadose zone and completing wells of sufficient diameter to allow sampling and the installation of appropriate instrumentation.

3. Rapidly changing river stage and velocities over short time periods represent hazardous conditions for channel and shoreline work.

4. The highly transient nature of the groundwater systems inhibits collection of "snap shots" of the spatial and temporal distribution of a contaminant or of hydraulic head, thus making it difficult to interpret groundwater flow directions and rates.

5. The geologic setting is quite heterogeneous, resulting in complicated flow patterns and plume concentration distributions. This geologic setting may require additional characterization to sufficiently understand observed contaminant behavior.

6. Instrumentation of the river channel bed in a river the size of the Columbia is both challenging and dangerous. Installation of direct sampling devices may not be practical. Targeted sampling and correlation with remote sensing and mapping data sets may be appropriate.

The established groundwater monitoring network includes conventional 10-cm (4-inch) ID monitoring wells. Most wells have screens that are 6.9 to $9.1 \mathrm{~m} \mathrm{(20} \mathrm{to} 30 \mathrm{ft})$ in length. These wells are intended to both provide head and water-quality data; because of the screens lengths, these wells tend to provide average head and water-quality data. Wells with shorter well screens and/or multi-level samplers would provide a higher resolution of the head and contaminant distributions. Data from such wells would also allow interpretation of three-dimensional flow and transport.

\subsubsection{Suggestions for Monitoring Well Network Design and Data Acquisition}

The panel makes the following suggestions for enhancement of the monitoring network and data acquisition using existing monitoring wells.

1. Examine how current well construction likely impacts observed head and contaminant distribution interpretations. Aquifer testing in selected wells could be done to determine if vertical flow is occurring between screened intervals and if aquifer zones of differing water quality are identifiable. 
2. Consider installing multi-level wells with short screens to further examine the vertical distribution of groundwater contamination and hydraulic heads in the Hanford and Ringold Formations.

\subsection{AQUIFER TUBE WELLS AND RIVER TUBE WELLS}

\subsubsection{Aquifer Tube and River Tube Construction and Integrity}

The installation of aquifer tube wells along the shoreline has provided valuable information on the lateral extent of the $\mathrm{Cr}^{+6}$ plumes entering the river. The completion process relies on the surrounding materials collapsing back against the tubes when the temporary drive pipe is removed; the collapsed materials assume the properties of undisturbed materials (as is depicted in Figure 3-1). This type of collapse generally should occur in saturated sand and gravel materials, as found at the Hanford Site. However, if the sampling device is not installed correctly, the annulus left behind by the temporary casing may act as a potential preferential pathway for surface water to travel down. In this case, if river water is unintentionally introduced into the sample, the sample intended to represent river bed water (groundwater originating from the up gradient contaminated sites) may underestimate the level of exposure of aquatic biota to $\mathrm{Cr}^{+6}$.

Figure 3-1. Schematic of Aquifer Tube and River Tube Installations

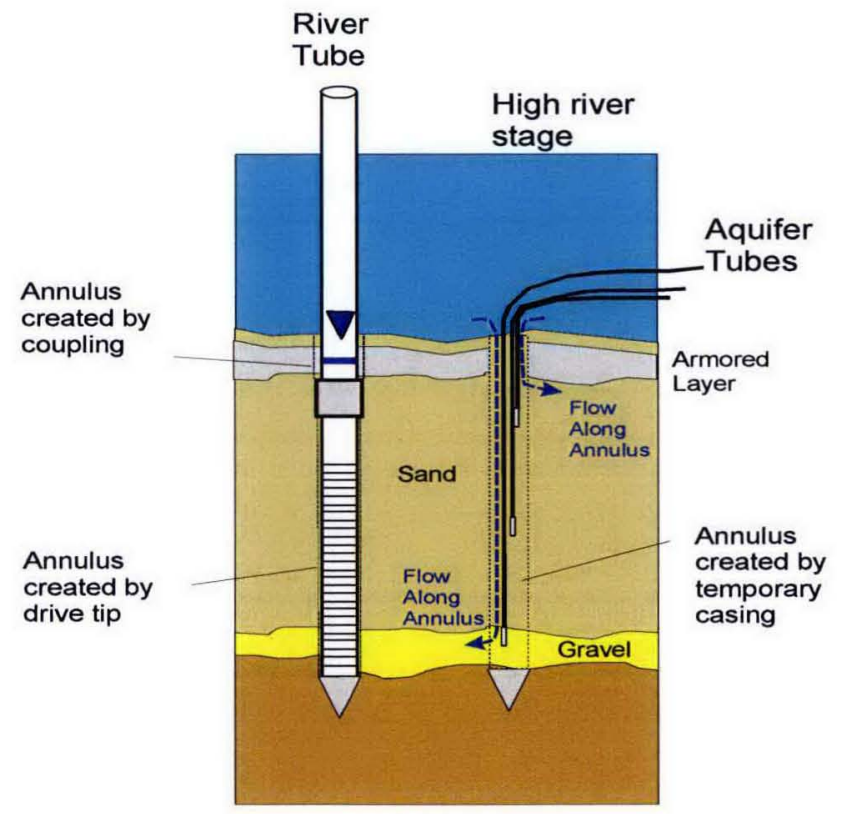

Water-quality results obtained using aquifer and river tubes may also be impacted by pumping them at high flow rates during sampling, as river water may be drawn into the open intervals. It appears that the design and method of installation of river tube wells installed in the 300 Area is less susceptible to sample dilution by river water. 


\subsubsection{Observations and Suggestions Regarding the Aquifer Tube Monitoring Network Design}

The panel makes the following observations and suggestions in regard to the aquifer tube monitoring network design.

1. If it has not already been done, integrity testing of selected aquifer tube installations should be performed to determine if samples are impacted by induced infiltration of river water. Testing could consist of:

a. Measuring hydraulic heads in the aquifer tubes using a potentiomanometer, Winter, T. C., et al. 1988, "The Design and Use of a Hydraulic Potentiomanometer for Direct Measurement of Differences in Hydraulic Head Between Groundwater and Surface Water," (if necessary) to assess the interconnectedness of the installation with the overlying surface water levels (or even just test for leaks in the tubes that may have been caused by freezing near the ground surface).

b. Introducing a dye tracer at the riverbed surface (directly around the aquifer tube) and then pumping the shallowest tubes to see if it shows up in the aquifer tubes too rapidly. As an alternate method, if the aquifer tube is submerged, use electrical conductance as an indicator of induced infiltration.

c. Inject dye into the deeper tubes and see if pumping of the overlying tube results in too rapid arrival of dye in the pumped water.

d. Pump individual well screen depths and observe if drawdown in the other levels is as expected. Use a multiport potentiomanometer that will allow simultaneous monitoring of head in each observation tube.

2. For future aquifer tube installations, if practical, consider using a sufficiently large temporary casing that will allow bentonite seals be installed (physically emplaced or injected) between screen intervals and up to the ground or riverbed surface as the temporary casing is withdrawn.

3. For future installations, also consider if practical, installing multilevel drive-point samplers like those described by, "A PCE Plume Discharging to a River: Investigations of Flux, Geochemistry, and Biodegradation in the Streambed" (Conant 2001) that do not require installing a temporary casing, and therefore, do not create an annulus that needs sealing.

\subsubsection{Source Water Quality to Identify Physical and Geochemical Processes Impacting Site and River-Bed Water Quality}

In groundwater/surface water interaction studies, it is very useful to identify natural conservative geochemical constituents that are preferably unique to one type of water or the other and are present at a "constant" concentration. Geochemical end-member mixing models can then be used to help quantify the complex processes affecting measured contaminant concentrations in the groundwater and river bed water. At the near-bank sites, specific conductance contrasts between river and groundwater have been used to suggest a dilution process that impacts $\mathrm{Cr}^{+6}$ concentrations observed in near-shore riverbed samplers. It is recognized that contaminant 
concentration sources (end members) are unlikely to remain constant over space or time. Other components such as nitrate or sulfate may also allow for additional comparisons of the mixing of surface water and groundwater. Nitrate, for example, appears to correlate with $\mathrm{Cr}^{+6}$ occurrences in riverbed pore-water samples (BHI 00778, 1996, Table 4-1)

\subsubsection{Observations and Suggestions Regarding Use of Source Water Quality to Identify Physical and Geochemical Processes Impacting Site and River-Bed Water Quality}

The panel makes the following observations and suggestions:

1. Additional evaluation of the application of specific conductance values to imply mixing of site water and river water should be conducted. Geochemical data should be evaluated to determine the major aqueous contributions to specific conductance in groundwater, and whether other unique parameters can be identified to enhance mixing models.

2. Caution should be used when attempting to transfer site-specific mixing analyses to sites with different hydraulic and or water-quality settings. New geochemical relationships may need to be established for each specific site.

\subsubsection{Hydraulic Gradients to Characterize Groundwater Conditions within the River Channel}

Vertical hydraulic gradients measured within the river-channel sediments can be used to characterize the direction of groundwater surface-water exchange, and when combined with the river-sediment hydraulic conductivity, used to calculate flux rates. Computed vertical-gradient values should be examined carefully, as some reported values are greater than one, a condition reserved for areas with unsaturated flow. In areas with large vertical gradients, such as measured at the 300 Area (Fritz 2008), groundwater exchange can be either high or limited. Verticalgradient data may also be used to suggest if channel armoring is acting to reduce or enhance water exchanges. Analysis of 100-D Area data may allow further characterization of the riverbed characteristics. Current work suggests that there is "no impediment in flow between the river and the unconfined aquifer, e.g., a low-transmissivity zone at the river bottom" in the 300 Area and 100 Area, (Peterson and Connelly, 2001). However, the high measured vertical gradients suggest that armored river-bed surfaces may act to restrict vertical exchange, flow would be predominantly horizontal towards preferential discharge locations where the armored layer is absent. If this were the case, vertical mixing and movement of waters may not occur to the extent flow modeling of a homogeneous system would suggest. Further investigations would be required to confirm or refute the presence of an armored layer in the river bed.

\subsubsection{Observations and Suggestions Related to Use of Hydraulic Gradients to Characterize Groundwater Conditions within the River Channel}

The panel makes the following observations and suggestions regarding vertical hydraulic gradient interpretations at the river.

1. Check all hydraulic gradient calculations for accuracy.

2. Examine hydraulic gradients of river and aquifer tubes for indications of overlying low hydraulic conductivity layers that may be impeding flow (e.g., the armored layer). 
3. Check Darcy Law calculations for accuracy, especially in situations where high hydraulic gradients suggest the presence of a low hydraulic conductivity layer.

\subsubsection{Presentation and Interpretation of Water Quality Data}

Unevenly and widely spaced data, such as those available to describe conditions at the 100 Area sites, are often difficult to synthesize into a 2- or 3-dimensional representation of contaminant distributions. Contoured concentration data should be carefully reviewed to determine if sufficient field data support the interpolation. The distribution of contaminants should further be assessed within the dynamic groundwater flow system.

\subsubsection{Observations and Suggestions Regarding Presentation and Interpretation of Water Quality Data}

The panel makes the following observations and suggestions regarding presentation of water quality data.

1. Representation of the contaminant distribution should be mapped using a number of approaches, indicating where uncertainty in the process is present. Results of the various alternative mapping approaches should be compared.

2. The dynamic nature of the contaminant distribution may be best interpolated using a calibrated solute transport model.

\subsection{MONITORING AND SAMPLING NETWORK DESIGN}

The review of the network design in the 100-D Area was done in the context of the documents provided and information presented at the workshop (particularly the presentation by Fritz (2008) and is intended to identify large data gaps. The intent of this section is not to critique installation techniques or suggest improved data analysis, but rather to suggest additional, alternative or new monitoring approaches that may address identified data gaps. The panel realizes that time, logistical, and budgetary constrains will limit the degree to which additional or new data collection will be accomplished. When these suggestions have been evaluated and those that are feasible within budget and schedule constraints are determined, additional data collection should focus on field testing at a few key locations. Any new data sets should be evaluated in the context of how additional data collection will shape remediation goals. Additional site characterization should include:

- further characterization of the lateral and vertical extent of the $\mathrm{Cr}^{+6}$ plume beneath the river;

- testing of the effect of channel bed armoring on the locations and rates of groundwater flux.;

- assessment of the role of the vadose zone as a source of $\mathrm{Cr}^{+6}$ to the fluctuating groundwater system;

- mapping the topography of the Ringold aquitard beneath the river;

- examining if the fine-grained basal aquitard beneath the unconfined aquifer in the Ringold is a source of $\mathrm{Cr}^{+6}$ to the shallow groundwater; 
SGW-39305, Rev. 0

- further characterizing the vertical distribution of contamination in the groundwater beneath the 100 Area sites, including the river banks;

- investigating the nature of the hydraulic divide beneath the river and its control on contaminant distribution in the river bed. 


\subsection{CHARACTERIZATION OF THE CR ${ }^{+6}$ DISTRIBUTION BENEATH THE COLUMBIA RIVER}

This is the largest and most important data gap to address. The riverbed is where the primary ecological exposure occurs and so knowing specific concentration and mass loading within this zone is important. Previous work by, "Delineating and Quantifying Ground-Water Discharge Using Streambed Temperatures," (Conant 2004) has shown that monitoring a plume at the riverbank is not sufficient to accurately determine conditions within a riverbed and that contamination there may be greater than what is detected at the riverbank. Some of the most valuable data at the site was collected in 1995 as part of the pore-water sampling of the riverbed (BHI 00778, 1996). There is need for more of this type of data to be collected to define the lateral and vertical extent of the contamination beneath the river, identify areas of preferential groundwater discharge, locate contaminant hot spots, and find high mass flux discharges. Sampling should be planned to occur during times when the $\mathrm{Cr}^{+6}$ flux to the river is expected to be the highest, which based upon previous studies, coincides with a period of low river stage, This sampling should be completed at locations assumed to be where groundwater discharge would be focused.

\subsubsection{Suggestions Regarding Characterization of the $\mathrm{Cr}^{+6}$ Distribution Beneath the Columbia River}

1. As previously suggested in 2.2.2.1, the panel suggests conducting pore-water sampling off-shore to attempt to delineate the areal extent of the plume beneath the river and locate the furthest distance off-shore that the plume has traveled. These furthest locations from shore are likely the deepest groundwater flow paths and may likely be subject to minimal dilution or dispersive processes associated with bank storage or true hyporheic zone mixing processes. Targeted pore-water sampling is suggested in areas of the high-flux groundwater discharge zones, because they likely will not be subject to significant attenuation of concentrations. Techniques to achieve this could include:

a. pore-water sample collection using divers, as was done in 1995;

b. barge-mounted direct-push equipment in concert with a depth-discrete sampler, e.g., the Waterloo Profiler, "Field Demonstrations Using the Waterloo Ground Water Profiler," (Pitkin et al. 1999), Geoprobe system, or BAT sampler. Special provisions should be made to try to make measurements at river stages that promote groundwater discharge and not surface-water recharge, i.e., during winter months. These installations will likely create holes through the armored layer, if present, so equipment with knockout tips should be used to ensure that any holes made can be grouted closed as the drilling rods are withdrawn.

c. passive flux meters, such as those described by, "Magnitude and Directional Measures of Water and Cr(VI) Fluxes by Passive Flux Meter,"(Campbell et al. 2006), to obtain time-averaged concentrations of chromium loading. This technique requires installation of wells to contain the devices; so they will be more difficult to deploy and retrieve than the direct-push integrated sampling systems. Other variations of similar semi-permeable membrane devices (SPMDs) may provide equally useful data. In reducing areas, emplacing ceramic beads and retrieving them and analyzing the precipitates that accumulate on them may be 
useful, "Metal behavior during surface-groundwater interaction, Silver Bow Creek, Montana." (Benner et al 1995).

2. Locate areas of high groundwater discharge. Heterogeneity in groundwater discharge is essentially the rule and not the exception, "Stream and Fluvial Plain Ground Water Interactions: Rescaling Hydrogeologic Thought," (Woessner 2000); (Conant (2004). The presence of shoreline seeps clearly illustrate that rather localized high discharges do occur at the site and are likely present further off-shore. In particular, high-flux preferential discharge zones will likely occur at holes or windows through the armored layer, if present, and where the Hanford or Upper Ringold deposits pinch out against the Ringold aquitard. To find these discharge areas, consider using the following techniques.

a. Lower the Columbia River to expose as much streambed as possible. Perform visual inspection of the exposed streambed as well as low-elevation aerial infrared photography (looking for thermal anomalies associated with groundwater discharge). Manual sampling of seeps, geological mapping, etc. can also be done at this time. The potential environmental impact of lowering the water level and exposing the riverbed will have to be assessed prior to such a technique being employed. The panel recognizes the difficulties associated with this approach.

b. Use geophysical surveys to identify geological variations. Use boat-towed continuous seismic reflection, electromagnetic (EM) methods, and ground penetrating radar (GPR) to determine geological contacts and clay versus sand contents, "Delineating Recharge to a River Valley Aquifer by Riverine Seismic and EM Methods," (Butler, et al 2004), "Use of Ground-Penetrating Radar and Continuous Seismic-Reflection Profiling on Surface-Water Bodies in Environmental and Engineering Studies," (Haeni, 1999). Although attempts to use GPR along the shoreline were deemed unsuccessful, because of lack of penetration (perhaps due to attenuation of the signal by clay), the method should be reevaluated for use, because in places where GPR does penetrate, it may indicate either loose fluvial sandy deposits or perhaps preferential discharge locations, (Conant 2004) where more permeable deposits are present and the armored layer is absent.

c. Use thermal methods to identify groundwater discharge. Although a prior attempt to locate discharge points on the Columbia River using a conductance/temperature drag probe, "Method for Locating Sediment Anomalies in Lakebeds that can be Caused by Groundwater Flow," (Lee 1985) was not completely successful (see report by Lee et al., 1997, "Locating Ground-Water Discharge in the Hanford Reach of the Columbia River"), there have been recent advances in thermal monitoring. Distributed temperature sensors (DTS) consisting of fiber-optic cables (100s of meters long) have the ability to detect very small temperature differences on a scale of $1 \mathrm{~m}$ on a frequency of seconds to minutes, (Lowrey, et al., 2007, Identifying Spatial Variability of Groundwater Discharge in a Wetland Stream Using a Distributed Temperature Sensor; Selker, et al., 2006a, Fiberoptics Opens Window On Stream Dynamics; Selker et al., 2006b, Distributed Fiber-Optic Temperature Sensing for Hydrologic Systems). Although they may experience some of the same challenges that the drag probe method experienced with respect to the rapidly flowing surface water masking any small 
groundwater discharges, it may be worth attempting at 100-D Area. It is reported that fiber-optic DTS is scheduled for testing in the 300 Area this summer, and, if successful there, it should be used on the 100-D Area reach of the river.

d. Investigate the possibility of salmon redds being locations of preferential groundwater discharge. Instrument a finite number of redds (in non-spawning times of year with similar river stages) with temperature sensors and obtain water quality samples. An investigation similar to that presented at the workshop by Hanrahan for the Snake River should be undertaken.

3. Assess chromium content of sediments. Collect sediment samples of the riverbed, particularly in areas that have been identified as reducing (e.g., locations in the 1995 pore-water sampling study that had low dissolved oxygen concentrations) and over the decades may have accumulated chromium in sediments to levels that are unacceptable for freshwater aquatic life (Buchman 1999). Moreover, if in the past the lower permeability Ringold clays have been exposed to high chromium concentrations flowing through the overlying permeable sediments, chromium may have diffused into the aquitard. Such back-diffusion has been documented for clays contaminated with chlorinated solvents in a cyclic pumping scenario that is somewhat analogous to periodic bank storage effects at Hanford, "A Controlled Field Evaluation of Continuous vs. Pulsed Pump-and-Treat Remediation of a VOC-Contaminated Aquifer; Site Characterization, Experimental Setup, and Overview of Results," (Mackay et al., 2000). The following characterization techniques may be of use to assess chromium concentrations in sediments:

a. Coring of sediments from a barge. The cobbles in the riverbed will make this technique difficult unless specialized drilling is employed (e.g., a small trackmounted mini-sonic rig using Lexan core liners). If relatively undisturbed sediment samples can be obtained with the pore-water still intact, an in situ distribution coefficient can be determined if pore water is sampled and analyzed.

b. Freeze coring. The advantage is that a potentially undisturbed sample can be retrieved, but the drawback is that the method will result in larger diameter, rather irregular and difficult to grout up shallow holes, which is a problem if lower permeability layers have been breached.

c. Core the top of the Ringold aquitard deposits and analyze the sediment concentrations with depth to characterize the vertical distribution or diffusion profile and determine the extent of chromium contamination that may be backdiffusing into the overlying permeable sediments.

\subsubsection{Determine the Role of the Ringold Upper Mud Aquitard in Contaminant Transport}

In some reports, the base of the unconfined aquifer, which is located within the Ringold Upper Mud Unit, is characterized as being the bottom of the system of concern, primarily because it has a low hydraulic conductivity (Figure 2-1). Delineating and defining this contact between finegrain sands in the upper part of the Ringold Upper Mud Unit and low permeability clay-rich beds, is important especially beneath the river where it is not certain if ancient scouring events have resulted in erosion through the sandy layers (upper part of the Ringold Upper Mud Unit or the Ringold E). The conceptual model of the deposits beneath the river suggests that the Hanford 
and sands in the upper portion of the Ringold Upper Mud Unit or Ringold E are the primary unconfined aquifers, which may not extend across the river. Because the underlying low permeability clays are assumed to be an aquitard, all the contaminated groundwater flowing in the overlying aquifers should discharge upwards into the river. However, if the clay-rich layers were scoured out and thick more permeable sands were deposited in its place, those deposits might allow the plume to travel further out beneath the river before discharging. It should be noted that the Ringold Upper Mud at the 100-D Area is not homogeneous and does not have negligible hydraulic conductivity.

\subsubsection{Observations and Suggestions Regarding the Role of the Ringold Upper Mud Aquitard in Contaminant Transport}

To assess the role of low permeability zones in the Ringold Upper Mud, the following techniques are suggested by the panel.

- Install monitoring wells a sufficient distance into the Ringold Upper Mud aquitard (10 to 20 feet) both on- and off-shore to determine the lithology and stratigraphy, hydraulic conductivity (well slug tests), as well as sediment and water quality, i.e., presence and concentration of contaminants. As always, care should be taken to properly seal the annulus of any borehole created to avoid preferential flow along the well installation and between formations.

- If possible, map the top of the Ringold Upper Mud aquitard beneath the river using geophysics (see above suggestions for characterizing the armored layer using EM or continuous seismic methods). Alternatively, direct-push drilling from a barge would be an alternative access method. Consider drilling on the mid-channel island, because it may provide an easier venue for obtaining geological data near that location.

- If the Ringold Upper Mud aquitard at this location is a very low hydraulic conductivity material, it should be analyzed for chromium to determine the potential for diffusion back into the river (see above item on assessing chromium content of sediments).

\subsubsection{Characterize Vertical Contaminant Distribution in Unconsolidated Materials Adjacent to the River}

The main reasons for characterizing the vertical distribution of contaminants in the unconsolidated materials adjacent to the river are to 1) identify high-concentration zones adjacent to the river and 2) determine if the plumes in the deeper groundwater flow paths are being diluted by near-shore bank-storage processes.

\subsubsection{Observations and Suggestions Regarding Vertical Contaminant Distribution}

As suggested earlier, multilevel monitoring wells or multiple depth aquifer tubes are recommended to better understand the vertical distribution of chromium. Depth-discrete measurements of water quality can be obtained through nested installations in the same borehole or Continuous Multi-channel Tubing (CMT) (Solinst Canada Ltd), as less expensive alternatives that can be used where the depth to water is within the suction limit. Where the depth to water is greater, the much more expensive Waterloo Multilevel Monitoring System (Solinst Canada Ltd) or Westbay Multilevel Well System (Schlumberger Water Services) could be utilized. 


\subsubsection{Characterize Flow from the Opposite Bank of the River and Identify Hydraulic Divides}

Depending on the magnitude and direction of groundwater flow from both sides of the river, the hydraulic divide may not be in the middle of the river. The position of the divide will determine the areas of the riverbed over which $\mathrm{Cr}^{+6-}$ contaminated groundwater is discharging. The assumption has been that the hydraulic heads are much higher on the opposite side of the river due to irrigation, which appear to be true downstream of the 100-D Area (Figure 2-2). If indeed the water levels are rather high on the opposite side of the river, the groundwater divide will likely be closer to the 100-D Area; if so, the potential area requiring remediation for contaminant discharges may be smaller than anticipated.

\subsubsection{Suggestions on Defining the Hydraulic Divide Beneath the River}

To obtain information on the location of the hydraulic divide (and the maximum lateral extent that the plume can travel under the river), the following activities are suggested by the panel.

- The traditional approach of installing wells and monitoring water levels on the opposite bank would provide a basis for determining flow directions toward the river.

- To truly map the divide beneath the river, multilevel hydraulic head data would be needed beneath the river cross-sectional arrays of piezometers that cover the full width of the river and span the full thickness of the permeable sediments beneath the river might be installed. Such instrumentation in a large, fast flowing and deep river would be difficult as discussed in "Assessing Water Travel Times During Riverbank Filtration, in Bringing Groundwater Quality Research to the Watershed Scale," (Dawe and MacQuarrie 2005).

\subsubsection{Estimate Contaminant Transport Parameters}

Three-dimensional representations of the transport of $\mathrm{Cr}^{+6}$ in the geologic settings of the nearbank locations requires well-defined dispersion and diffusion coefficients, and distribution coefficients. Existing data bases may need to be enhanced by lab experiments, if literature reviews do not provided needed values.

\subsubsection{Observations on Transport Parameter Values}

To obtain the transport parameter information, the following is suggested by the panel.

- Perform a review of existing site reports and other published literature as needed to understand chromium behavior. Determine chromium diffusion coefficients, partitioning coefficients, and precipitation/dissolution kinetics for relevant reactions to conduct transport modeling similar to the uranium transport modeling done for the 300 Area.

- If necessary, conduct laboratory column and batch experiments with site materials (contaminated and uncontaminated) and site groundwater (contaminated and uncontaminated) to determine diffusion characteristics of the Ringold clays and the effects of flushing contaminated Hanford and Ringold sediments with clean surface water.

- Examine the possibility of conducting in situ-column tests in the streambed similar to that described by, "In Situ Retardation of Trace Organics in Groundwater Discharge to a 
Sandy Stream Bed," (Winters and Lee 1987) to measure in situ velocities and breakthrough characteristics.

- Determine realistic and site-specific dispersion coefficients for transport through the very high hydraulic conductivity Hanford deposits.

\subsection{DATA ANALYSIS}

\subsubsection{Temperature Data and Pumping Tests}

The purpose of this section is to examine both previous and proposed 100-D Area investigations to see if the characterization and understanding of the site could be improved through data mining and better data analysis techniques not discussed elsewhere in this report. Some of the topics or suggestions may appear repetitive; however, this is because the data used may be discussed elsewhere, but the method or intent of the data analysis is different. Again each suggestion may not be appropriate or may have already been completed; we expect careful evaluation of suggested tools and pilot scale analyses or application to test the usefulness of the method to expand knowledge of $\mathrm{Cr}^{+6}$ transport and groundwater river interactions.

- Collect vertical temperature profiles in wells to analyze groundwater flow and well integrity.

- Analyze existing subsurface specific conductance and temperature data together.

- Use temperature analysis techniques to better constrain flow and mass transport modeling.

- Model two-dimensional horizontal heat transfer between the river and groundwater.

- Perform pumping tests for local hydraulic response and temporal concentration and temperature variations.

The benefits of using temperature as a tracer to determine flow directions and magnitude of fluxes in groundwater/surface water interactions studies is well known and summarized, USGS Circular 1260, Heat as a Tool for Studying the Movement of Ground Water Near Streams; "Heat as a Groundwater Tracer," (Anderson 2005). Streambed temperature measurements have been used to rapidly and successfully map and quantify groundwater discharge zones in riverbeds, (Conant 2004; Schmidt et al. 2007), but the transient nature and rapid reversal of flow directions due to changing river stage likely precludes applying this particular mapping technique to the Columbia River site.

However, time-series measurements of temperatures in the streambed could be combined with one- and two-dimensional flow and heat transport modeling to obtain water fluxes over time. A considerable amount of streambed temperature data has been collected by pressure transducers both in on-shore wells and at locations beneath the river; it appears that the data have not been modeled or examined for suitability for use in modeling. Two key factors or criteria will determine if the data can be analyzed in this new way: (1) the exact depth beneath the top of the riverbed where the temperatures were measured by the transducer needs to be known, and (2) if the pressure transducer was deployed in a well, the water level in the well should not have been allowed to move up or down significant distances in the well bore in response to head changes (too much movement will limit or preclude the use of the data because temperatures are 
presumed to be equal to the temperature immediately outside the well at the location and should not be an artifact of water movement within the well).

A data analysis method described by "Estimation of Hydraulic Conductivity in an Alluvial System Using Temperature," (Su et al. 2004) appears to have not been previously applied at the site and could be applied to both previously collected and newly acquired data. In this method, temperatures measured by pressure transducers in monitoring wells adjacent to a river are used along with two-dimensional modeling with VS2DHI (Healy and Ronan, 1996; Hsieh et al., 2000) to estimate groundwater and induced surface water infiltration fluxes. However, the Su et al. (2004) method uses time-series data from a single location to calibrate a two-dimensional model, which necessarily requires certain assumptions to be made that might compromise the veracity of the solution obtained if applied to the Hanford Site.

Another analysis technique is to model vertical profiles of riverbed temperatures over time at a specific location, USGS 2337, 1989, Use of Temperature Profiles Beneath Streams to Determine Rates of Vertical Ground-Water Flow and Vertical Hydraulic Conductivity; USGS 99-4212, Numerical Simulation of Vertical Ground-Water Flux of the Rio Grande from Ground-Water Temperature Profiles, Central New Mexico. Models such as VS2DHI (Healy and Ronan 1996; Hsieh et al. 2000) in one-dimensional mode can be used to determine if flow is indeed truly vertical at a location. If a good fit to the observed temperature data cannot be achieved using reasonable input data, three alternative explanations exist: 1) the flow likely has a horizontal component that requires a two-dimensional approach, 2) it may be indicative of a lowconductivity flow layer (e.g., the armored layer) having greater influence than originally thought, or 3) it may be indicative of compromised well installation. The method provides time varying groundwater flux data and if the temperature data are used with hydraulic head data, it can serve as a valuable constraint that can improve overall accuracy of the flow modeling.

Active stressing of the system using pumping tests has not been previously tried as a characterization method near the river; it could provide data and insights that otherwise could not be obtained by passive monitoring of the system. Pumping tests could be performed on larger diameter wells that would stress the aquifer system. Monitoring of the local hydraulic response and the variations in contaminant concentration and temperature in the effluent over time could 1) help quantify the mass of contaminants discharging to the river, "New Methodology to Investigate Potential Contaminant Mass Fluxes at the Stream-Aquifer Interface by Combining Integral Pumping Tests and Streambed Temperatures, (Kalbus et al. 2007) or 2) determine to what extent the contaminants and water quality may be vertically stratified within the aquifer, "Modeling of Contaminant Movement Near Pumping Wells: Saturated-Unsaturated Flow with Particle Tracking," (Akindunni et al. 1995); "Effect of Well-Screen Placement on Recovery of Vertically Stratified Contaminants," (Conant et al. 1995). Pumping tests were likely performed as pre-design activities for the current recovery wells, and, if the data were re-examined, it might provide more than the basic aquifer test analyses, with results that include hydraulic parameters like hydraulic conductivity and specific yield. The new pumping tests near the river would also provide hydraulic information. One acknowledged problem with conducting a pumping test is that the discharge water will likely need to be captured, stored, and treated, either at the nearby pump and treat facility or at the onsite Effluent Treatment Facility.

\subsubsection{Comments and Suggestions Regarding Data Analysis}

The panel suggests the following data analysis activities. 
1. Review temperature and conductance time $=$ series data already obtained from pressure transducers in wells near and beneath the river. Determine the data's suitability for use in heat and contaminant transport modeling.

2. Obtain vertical profiles of riverbed temperatures to model and determine if flow is primarily vertical, two-dimensional, or three-dimensional.

3. Use temperature and specific conductance data along with modeling to evaluate well integrity.

4. Use temperature and specific conductance data (e.g., as tracers) as secondary calibration targets to constrain and improve flow and transport simulations of groundwater surfacewater interactions.

5. Consider performing pumping tests in the contaminated aquifer, while monitoring effluent concentrations. Analyses would help determine the amount of mass loading of the river, whether the contamination is stratified in the aquifer and basic hydraulic parameters. 


\subsection{THE ROLE OF MODELING AND CURRENT MODELS}

\subsection{ROLE OF MODELING}

Modeling plays a crucial role in assimilating the wide variety of available information and the conceptualization of various processes at multiple spatial and temporal scales to facilitate a comprehensive understanding of

- Groundwater flow and contaminant transport, within various media at and in the vicinity of the Hanford Site and

- The interactions of the processes along the interfaces of the various media, for example the Columbia River/groundwater interface.

Experiments conducted using numerical models further assist in enhancing understanding of complex processes. A thorough understanding of the flow/transport systems and associated processes provides the capability to evaluate various scenarios that may lead to successful deployment of site-specific remediation and containment systems, the effectiveness of which may also be assessed by the model prior to and along with pilot studies and full-scale operations.

Modeling further provides a means of

- Evaluating uncertainty and risk, which is useful in better understanding the ambient and remedial operation systems in a probabilistic framework,

- Prioritizing and designing of field experiments and monitoring programs by identifying data gaps and the most sensitive data parameters, and

- Evaluating effectiveness of remedial systems, results of which may also be assessed by the model to note reductions in uncertainty and/or risk.

Essentially, the role of modeling is to assimilate all the information obtained as discussed in the previous sections, with mass balance equations for flow and contaminant transport to provide a spatially and temporally detailed understanding of system dynamics at various spatial and temporal scales to enable effective site management.

Modeling has played an important role at the Hanford Site to understand various processes and operations.

- Regional groundwater flow and transport modeling has been conducted to evaluate historical and current water levels and contaminant migration for various plumes of concern.

- Vadose-zone flow and transport models have been used to understand past and possible future contaminant migration from source zones, such as the tank farms, to the water table.

- Local two-dimensional particle tracking modeling experiments have been conducted (representative of 100-H Area) in steady-state and transient modes to examine flow patterns in the zone of groundwater/river interaction and groundwater discharge and seepage locations resulting from daily and seasonal fluctuations in river stage. This modeling has provided useful observations regarding bank storage and flow behavior in the hyporheic zone, and suggests dynamic differences resulting from steady-state and transient simulation cases. 
- Local two-dimensional flow and transport numerical modeling experiments have been conducted in the 300 Area to evaluate the response of uranium concentrations to the dynamics of the groundwater interaction zone.

However, evaluation of the flow and transport processes has not been completely achieved due to a lack of:

- Comprehensive assimilation of system data

- Detailed conceptualization of geological media and

- understanding of spatially and temporally varying flow and transport processes over the site.

A thorough understanding of these site-specific processes is essential for accurate evaluation of the interaction between groundwater and the Columbia River as it relates to fluid and mass exchange between the two water regimes. Accurate evaluation of these processes will facilitate optimal design of remediation systems for treatment of $\mathrm{Cr}^{+6}$ in groundwater in the 100 Areas.

\subsection{LOCAL AND REGIONAL MODELS}

The regional model provides a good basis for evaluating site-wide water-flow and contaminanttransport patterns, and regional boundary conditions for detailed analyses at finer local scales. The local two-dimensional particle tracking model has also provided extremely useful observations regarding bank storage and flow behavior in the transition zone and suggests dynamic differences resulting from steady-state and transient simulation cases. However, as additional local-scale conceptual models are developed to support design and performance evaluation of remediation systems, the corresponding numerical models may include a threedimensional representation of groundwater movement with the Columbia River as the center of the area of interest.

The main features of the current numerical model (which follows from the current conceptual understanding) that may be enhanced include the following.

- The two-dimensional cross-sectional model does not consider groundwater flow in and out of the profile, whereas surface-water groundwater interactions likely occur in threedimensions. This is especially the case for hyporheic flow, in which the river's momentum can direct river water into the subsurface at the upstream end of riverbed formations, or within channel deposits that create preferential flow paths, which extend from the surface into the hyporheic zone.

- Treating the center of the river as a flow boundary neglects the interactions on both sides of the river and their resulting effects on plume migration to the river. Alternatively, having the river as the center of the local model brings in dynamics from both sides of the river to better evaluate the discharge locations within the river or along the river banks.

- The current bottom and lateral river boundaries may be ignoring significant deep flow paths discharging far from shore.

- Treating the top of the Ringold Upper Mud aquitard as the lower model boundary ignores the dynamics of flow in/out of the underlying sediments, which may affect flow behavior at the local river interaction scale. The model domain may be extended downwards into the lower permeability sediments, so that the possibility for advection and diffusion of 
contaminants into and out of the mud before being discharged into the river can be considered.

- Particle tracking does not provide the full picture that would result from small-scale advection, dispersion, and diffusion. A better understanding of off-shore, on-shore, and hyporheic-zone mixing dynamics may be obtained by performing advective/dispersive transport simulations. This modeling allows for predictions of contaminant breakthrough dynamics, and can be used to evaluate whether contaminant fluxes to the river will likely increase or decrease in time, depending upon whether the peak of the breakthrough curve has reached the river. Furthermore, advective/dispersive transport simulations could be used to assess the effects of future trends in river-stage dynamics on contaminant fluxes to the river. As described later in this section, these simulations should be cast in a probabilistic framework to determine the most likely predictions of contaminant breakthrough based on uncertainty in sediment heterogeneity and other model parameters. As suggested earlier, the Transition Probability Geostatistical (TPROGS) Model, Carle (1999) or a similar model should be used to generate likely distributions of sediment heterogeneity (realizations) for predicting average contaminant breakthrough to the river and the corresponding uncertainty.

- Uniform material properties do not provide a complete picture of mixing. Inclusion of geological heterogeneities, including the armored layer, may significantly affect bank storage and flow in the hyporheic zone within the 100-D Area and the associated transport of contaminants to the river.

\subsubsection{Suggestions for Regional Modeling}

The suggestions for further regional modeling include the following.

- The regional model domain should be extended to the other side of the Columbia River.

- The model domain should include the aquitard beneath the unconfined aquifer to note flow effects at a local scale and include it as a possible source of contamination.

\subsubsection{Suggestions for Local-scale Modeling}

Suggestions for further local-scale modeling address the above limitations.

- Consider three-dimensional modeling and include results from activities suggested in previous sections of this report.

- Include the full width of the river within the local model and do not treat it as a lateral boundary.

- Include the aquitard beneath the base of the unconfined aquifer in the model domain to note flow effects at a local scale and include it as a possible source of contaminants

- Include advective dispersive transport simulations

- Incorporate smaller-scale heterogeneities within the model.

The panel also consideration of modeling the historical changes in the water table from the time during full-scale site operations to the present to further understanding of how these changes may have impacted the migration of chromium in the subsurface, possibly promoting downward 
transport into the aquitard. This modeling should help guide installation of new monitoring wells and coring of underlying aquitard.

\subsection{POTENTIAL USEFULNESS OF A 300-AREA TYPE MODEL}

Even though the 300 Area model is situated further downstream from the 100 Areas and hydrologic conditions are somewhat different, the approach used to examine this site should be evaluated to determine if a similar approach is applicable at the 100 Areas. Research ongoing in the 300 Area suggests that the observed contaminant "smear" zone in the unsaturated zone may also be present in the 100 Areas, due to fluctuations in water levels adjacent to the river. This research also demonstrates the utility of local models in conducting numerical experiments, performing sensitivity analyses, and examining alternative conceptualizations to understand system dynamics and help design monitoring programs.

At the 100 Areas, alternate conceptual models tested at the local scale may include dual porosity flow and transport (representing the aquifer heterogeneities or even to conceptualize the underlying aquitard), transport into and out of the aquitard, inclusion of onshore and offshore seeps, and even simulations at a scale representing one seep location with different seep lengths and angles to the shoreline, onshore and under the river. Numerical experiments may also be conducted to better understand the small-scale transport processes, including understanding the pore-level processes such as whether displacement with surface water and minor dispersion at the plume's leading edge (not "mixing") is occurring. They can be used to identify where true dispersion and diffusion occurs. Such experiments, alternative conceptualizations, and sensitivities can provide a good understanding of the variability that may or may not be inherent in the results that affect the site objectives. Further, these local models can provide ensembles of answers to the questions on concentrations within the salmon redd zone or the dilution attenuation between onshore wells and offshore aquifer tubes.

Besides testing different conceptual models of the system, modeling should be used as a tool to test and optimize different remedial/containment strategies to meet the site objectives. Modeling can be used to assess potential up-gradient sources of contaminants and to examine effective strategies to handle those sources as well as to meet site objectives efficiently. Strategies that a model can evaluate include source-zone remediation, pump-and treat, redox barrier technology, onshore hydraulic barrier systems, and offshore barrier systems. Modeling can assess the effects of varying pumping rates as river stage rises and falls or can quantify the effects of river stage, seepage, and the associated transport of oxygen and other constituents on the permeable reactive barrier or other in situ technologies under consideration. The modeling can also be used to optimize river-stage management with respect to controlling seasonal and daily fluctuation frequencies and amplitudes to effectively dilute groundwater outflow within the hyporheic zone with river water, and with respect to dynamically manipulating offshore and onshore discharge locations away from ecological receptors. 


\subsubsection{Suggestions Regarding Numerical Experiments and Conceptualizations}

Suggestions for further numerical experiments, sensitivity analyses, or alternative conceptualization studies include the following:

- dual porosity transport to represent heterogeneities and the aquitard beneath the unconfined aquifer

- inclusion of onshore and offshore seeps and other heterogeneities into simulations

- perform simulations at the scale of a seep to examine pore-level processes

- perform sensitivity analyses on the regional and local scale models

- perform Monte Carlo simulations on local-scale models to note uncertainties

- simulate potential up-gradient sources

- simulate remedial and containment strategies including source-zone remediation, pumpand treat, redox barrier technology, onshore hydraulic barrier systems, and offshore barrier systems

- Optimize remedial and containment strategies for effective and efficient operation. 
SGW-39305, Rev. 0

This page intentionally left blank. 


\subsection{ROLE OF GROUNDWATER SURFACE WATER INTERACTIONS IN SELECTION OF REMEDIAL ALTERNATIVES}

\subsection{VIABILITY OF MONITORED NATURAL ATTENUATION AS A COMPONENT OF THE REMEDIATION SYSTEM FOR 100-D AREA}

Like many hazardous waste sites, the final remedy for the 100-D Area will consist of a variety of remedial activities, technologies, and treatment trains. The current interim remedial actions at the site include aggressive remedial actions, such as the pump and treat and the passive ISRM system and, although not explicitly stated as such, monitored natural attenuation (MNA) near the river. The interim groundwater cleanup targets for $\mathrm{Cr}^{+6}$ in the pump and treat system $(22 \mu \mathrm{g} / \mathrm{L})$ and the ISRM barrier $(20 \mu \mathrm{g} / \mathrm{L})$ have been set with the expectation that the groundwater discharging to the river will be subject to at least a 1:1 dilution, which will result in concentrations below the ambient freshwater aquatic life chronic toxicity target value of $11 \mu \mathrm{g} / \mathrm{L}$. Although not explicitly stated as such, MNA is the proposed remedial action for the chromium plume as it reaches the shoreline.

The panel was asked to evaluate whether this assessment of the dilution and reduction of contaminants near the river was reasonable and whether it would continue to be a viable remedial alternative as part of the overall remedial actions at 100-D Area. To date, the focus of the work near the river has been primarily on characterizing the dilution and mixing of the contaminant plume reaching the river rather than taking a systematic and comprehensive approach to evaluating MNA using standard protocols and guidance available for that purpose. As remedial actions move forward at the site, the criteria for demonstrating MNA for inorganic compounds needs to be applied (USEPA 1998, 1999, 2007a, 2007b) and ultimately a monitoring plan needs to be put into place to confirm that attenuation is proceeding as projected.

To demonstrate natural attenuation along the shoreline, the proponent should show that (1) the reduction of contaminant concentrations is caused by chemical or biological attenuation of the contaminant or (2) the plume has stabilized horizontally and vertically (i.e., the plume is not growing in size, but is shrinking or remaining constant, or (3) a statistical reduction in the contaminant concentrations along specific flow paths can be shown (USEPA- USEPA/600/R98/128, 1998, "Technical Protocol for Evaluating Natural Attenuation of Chlorinated Solvents in Ground Water,"; USEPA, 1999, OSWER Directive 9200.4-17P "Use of Monitored Natural Attenuation at Superfund," 1999). Even for simple plumes in relatively homogeneous aquifers, it can be difficult to place monitoring wells along the centerline of a plume (i.e., a single flow path) to document the reduction of concentrations with distance, stabilization, or the shortening of the plume over time. The highly dynamic nature of the river stage and water levels in the aquifer means that in the 100-D Area, it will be very difficult, if not impossible, to place a series of wells along an exact flow path. Therefore, the plume needs to be evaluated in its entirety to show that it is shrinking or that its concentrations are being reduced. Because the full extent of the plume has not been defined beneath the river, by default, the only data available to support the proposed MNA remedial alternative is the reduction in concentrations observed in the aquifer at the shoreline and in the shallow pore water of the streambed.

Although concentrations have been demonstrated to have declined over time at several locations along the shoreline and in the riverbed pore water, the data set is not sufficiently compelling to support the conclusion that MNA has or can reduce all groundwater concentrations to acceptable levels prior to the chromium-contaminated water contacting ecological receptors of concern. 
Monitoring of water quality has focused on two locations where the interstitial water is primarily surface water (i.e., a surface water flowpath through the geological materials). The two locations investigated are the zone of bank storage caused by changes in river stage and reversed hydraulic gradients; the other is the topographically induced hyporheic within the stream channel and associated sediments (i.e., BHI 00778, 1996, pour water study).

The working hypothesis for groundwater surface-water interactions is that mixing of waters will result in at least a 1:1 dilution of contaminated water. The terms "mixing" and "dilution" give the connotation that the groundwater has been subject to turbulent mixing when it is likely that, despite velocities on the order of meters a day, groundwater flow is still laminar. So called "mixing" would then primarily be by the slow and weak processes of dispersion and diffusion that would occur at a relatively thin interface between the two types of water. Geological heterogeneities may also play a role in causing apparent mixing of the different waters. If contaminated groundwater is present in a volume of geological material that contains a lower hydraulic conductivity lens of material, and then the area is invaded by clean bank storage (i.e., surface) water, some of the contaminated water may remain behind in the lens to slowly advect and diffuse out into the surrounding surface water. Because the spatial extent of the ecological receptor of concern (e.g., the hyporheos) has not been delineated, it can not be stated with certainly that all the mixing of waters occurs prior to (i.e., in a zone outside of) the habitat of the biota.

One other concern is that there is potential for groundwater to contact hyporheic and benthic zone aquatic life and discharge to the surface water without undergoing any mixing or reduction in concentration. Figure 6-1 shows the current conceptual model for groundwater and surface water mixing at the site. It essentially assumes that bank storage water at the shoreline and beneath the river combined with hyporheic zone mixing is sufficient to penetrate the full thickness of the aquifer and contact all of the discharging contaminated groundwater and, therefore, alters its concentration. In this scenario, when the river stage drops, the mixture of waters that then discharges back to the river will supposedly be diluted and no undiluted groundwater will discharge to the river. An alternative and potentially more realistic, conceptual model (Figure 6-2) shows the potential effect of the armored layer and possible preferential pathways caused by geological heterogeneities. Here, it is more clearly shown that the bank storage water (clean surface water) only mixes with the groundwater at the interface between groundwater and surface water. The infiltration of surface water simply displaces the groundwater that then has to take a different flow path to reach the river (e.g., through the deeper Ringold deposits or move laterally down river before reaching the river). This bank storage is expected to occur primarily at the shoreline and not beneath the river, because of the presence of the armored layer. 
Figure 6-1. Current Conceptual Model of Groundwater and Surface Water Mixing at High RiverStage.

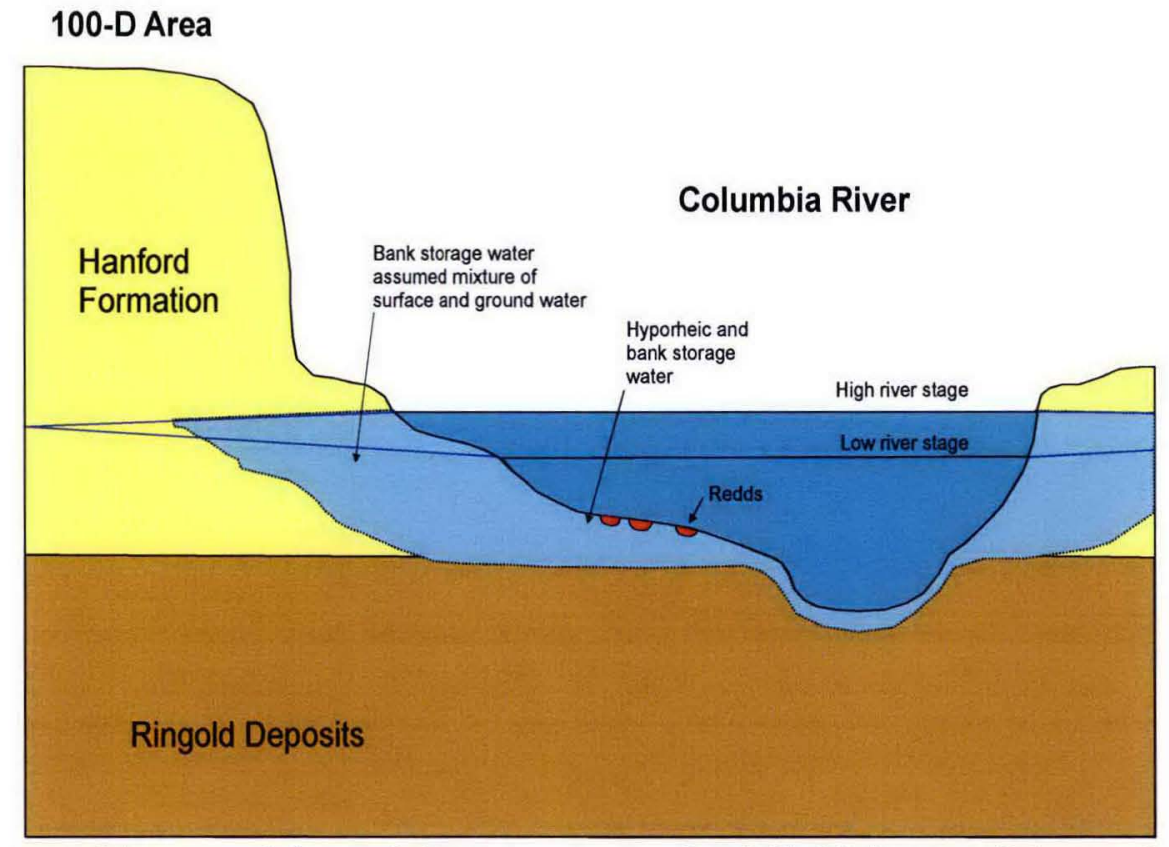

Assumes no armored layer and that mixing occur over the full thickness of the sand and gravel aquifer.

Figure 6-2. Conceptual Model of High River Stage that Incorporates the Effect of a Semicontinuous Armored Layer.

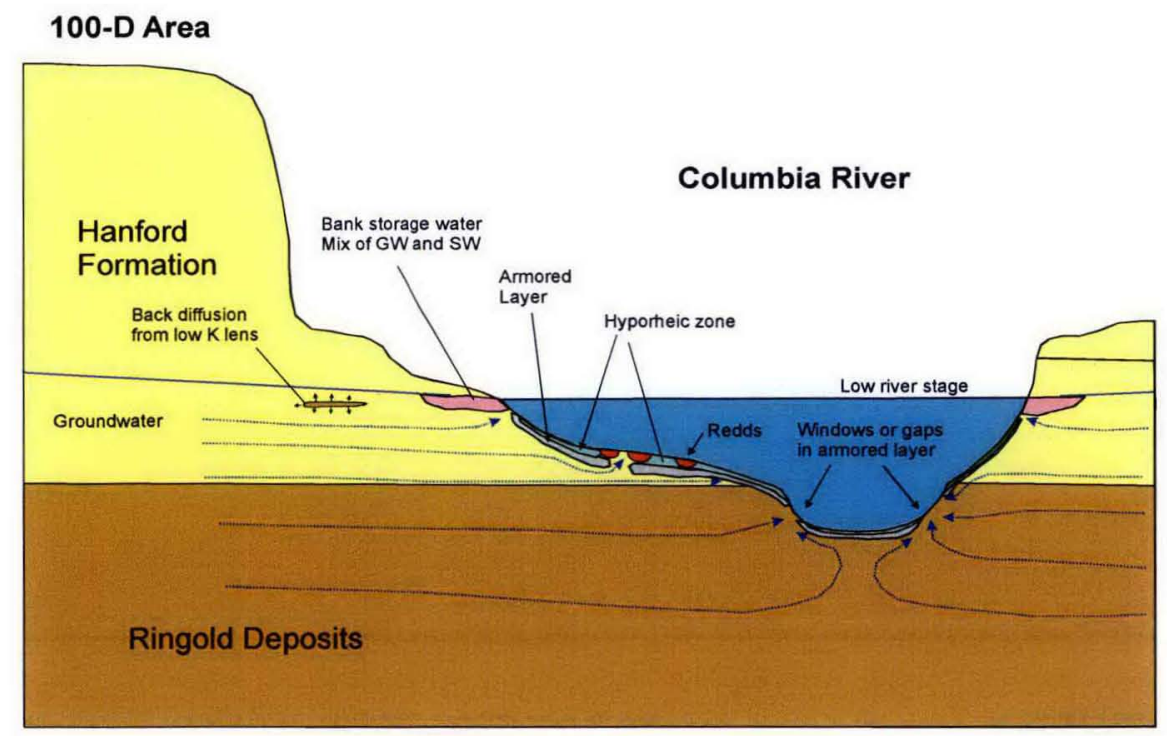


Groundwater and surface water mix at the leading edge of the bank storage (dispersion front) and hyporheic zone water. Some back diffusion of contaminants from a low hydraulic conductivity layer may also contribute to apparent groundwater/surface water mixing.

The armored layer reduces and limits the amount of surface water that can move vertically through it, but because the armored layer does not extend up the side of the river bank, once the river level rises, it can more easily infiltrate through the side of the river bank than through the armored river bottom (Figure 6.2). This type of enhanced infiltration behavior through river banks at high river stage has been observed in other rivers in Europe. As shown in Figures 6-2 and 6-3, deeper groundwater will likely be able to flow under this area of bank storage water (i.e., surface water in the subsurface) and move out a considerable distance from shore (protected by the overlying armored layer) without mixing with surface water. At low-river stage (Figure 6-3), focused discharge of groundwater at windows through the armored layer will likely displace any previously infiltrated surface water from the high-river stage (Figure 6-2) and undiluted groundwater will discharge directly to the river. During the fall Chinook spawning period, when the river stage is maintained at its lowest level, the highest amounts of undiluted groundwater discharge would be anticipated to occur at these locations. If the Chinook have sought out (or possibly even created) these preferential discharge zones to construct redds, this could be the worst possible contaminant exposure scenario for the eggs.

Figure 6-3. Conceptual Model of Low River Stage that Incorporates the Effect of Windows through the Armored Layer.

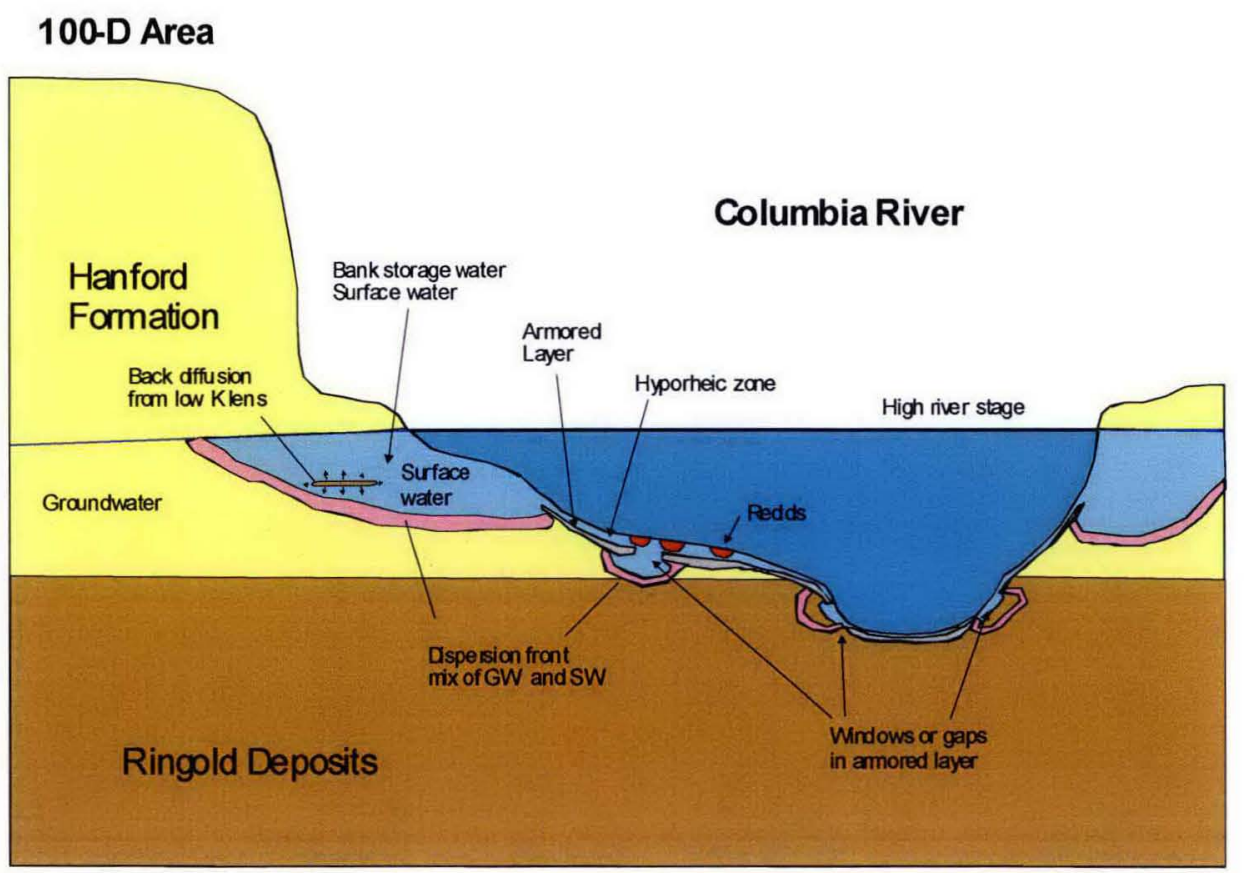


Undiluted aquifer groundwater is able to discharge through the windows and deeper flow from the Ringold discharges further off-shore.

As stated before, evaluating the effectiveness of MNA requires knowledge of the groundwater flow paths and the extent of the plume. Although discussed previously, the lack of knowledge regarding the geology beneath the river could play a critical role in determining where to monitor for MNA. Figure 6-4 shows what the potential effects of a scoured out paleochannel in the Ringold aquitard would have on groundwater flow. If this channel were backfilled with higher permeability deposits, groundwater from the 100-D Area would have the potential to travel much farther out into the channel and potentially even reach near the far bank, depending in part on the flux of groundwater from the opposite side of the river. Although difficult to show in a cross section, there is also the possibility that groundwater flow could reach the deepest part of the scour zone channel and then move horizontally in the downstream direction to ultimately discharge some distance downstream of the site.

Figure 6-4. Conceptual Model of Low River Stage that Incorporates the Effect of a Scoured-out Ringold Aquitard Beneath the River.

100-D Area

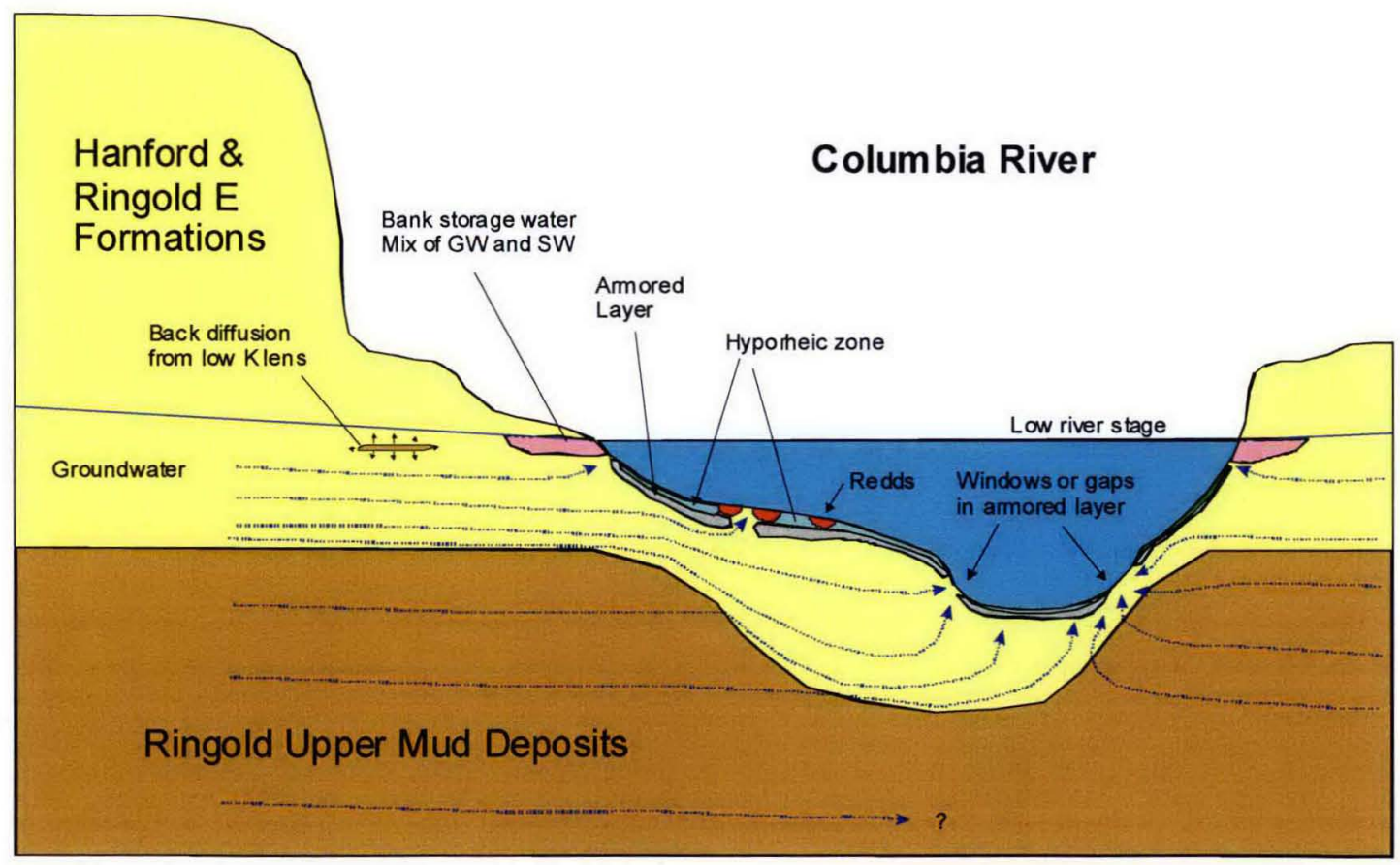

Undiluted groundwater is able to discharge through the windows both in the unconfined aquifer and the deeper Ringold deposits; flow discharges further offshore and can almost reach the opposite side of the river.

It also should be remembered that dilution is not the only mechanism that can contribute to attenuation of $\mathrm{Cr}^{+6}$. Moreover, it should be noted that USEPA $(2007 \mathrm{a}, \mathrm{b})$ apparently will not accept "dilution" as the sole attenuation mechanism for MNA. $\mathrm{Cr}^{+6}$ reductions to $\mathrm{Cr}^{+3}$ and precipitation can occur as well as sorption onto iron and manganese oxides and hydroxides. Factors that might mitigate these other mechanisms would be a low $\mathrm{pH}$ that would destabilize iron hydroxides and low Eh, which might cause the iron hydroxides to dissolve (but also would favor $\mathrm{Cr}^{+6}$ reduction). A review of existing data or collection of new geochemical data would be 
of use in assessing and predicting if reducing conditions are present and if attenuation by precipitation is naturally occurring at specific locations on the site.

To demonstrate that MNA is a viable remedial approach, it will be necessary to investigate and address the above concerns. If the preferential discharge locations or worst-case exposure locations and times can be identified and then monitored to show that concentrations are acceptable, MNA may be viable. If concentrations at those locations are too high, then the opportunity exists to combine MNA with additional remedial technologies (up-gradient and possibly on-shore) that clean up just that small portion of the plume that seems to be causing the problem. One could envision a situation where large parts of the groundwater plume can be allowed to discharge toward the river unaltered to naturally attenuate and have targeted remediation address high-concentration areas where attenuation would not be sufficient.

\subsubsection{Observations and Suggestions Regarding Monitored Natural Attenuation}

The panel makes the following observations and suggestions for activities to assess the viability of natural attenuation of the chromium plumes as a component of a more active up-gradient remedial system.

1. Determine where attenuation needs to occur in order to be in compliance and not adversely affect aquatic life. Do groundwater concentrations need to be reduced prior to entering the transition zone? If the answer is yes, MNA may not be a viable alternative, because biota is exposed to groundwater prior to undergoing any mixing within the transition zone.

2. Perform investigations to determine which conceptual model of flow and attenuation is correct (Figures 5-1 to 5-4). Use this information to perform targeted sampling of potential problem areas.

3. Characterize the armored layer and determine its role in influencing groundwater flow paths. The area downstream of 100-D (between the island and the Horn) is one area where a low permeability layer exists and an armored layer likely exists in most areas.

4. Install multilevel groundwater quality monitoring points to determine if deep groundwater flow-paths are allowing groundwater to circumvent dilution effects from near-shore bank-storage.

5. Identify preferential groundwater discharge locations beneath the river to determine if they represent places of high or unacceptable concentration exposures.

6. Do not focus completely on pore-water concentrations, but also examine chromium concentrations in sediments, because chromium can accumulate by precipitation and sorption.

7. Follow USEPA protocols (USEPA $2007 \mathrm{a}, \mathrm{b}$ ) for properly evaluating and demonstrating MNA as a remedial alternative. 


\subsection{OPTIMIZING REMEDIATION}

As is currently understood by DOE Richland and Fluor Hanford, a chromium remediation system for the 100-D Area should take into account the groundwater-surface water interactions discussed in the preceding sections. In particular, the overall remedy is relying upon groundwater/surface water interactions (MNA) to dilute contaminated groundwater that exits the site and reaches the river. River-stage fluctuations occur on several time scales (daily, seasonally) and these can also influence the performance of engineered remediation systems depending primarily on distance from the river. For example, if "source zone" remediation is undertaken at distances of about a $1000 \mathrm{~m}$ or more from the shoreline where the highest known dissolved chromium concentrations currently exist, the available data suggest that the daily riverstage fluctuations will have relatively little impact on flow directions or water chemistry. On the other hand, the ISRM treatment zone, which is located about $200 \mathrm{~m}$ from the river may be experiencing changes in the influx water chemistry as a result of seasonal and possible daily reversal in the groundwater flow direction. Along similar lines, it is possible that pump-and-treat extraction wells may, during high-river stage when hydraulic gradients are reverse, be extracting relatively low-concentration bank-storage waters; and so, some efficiency may be gained by reducing pumping rates during such periods.

As discussed in Section 4.4, the evaluation of the role of the river on such remediation schemes is best explored by additional data collection (discussed in Section 3) and then incorporation of all existing and new data into in a model to evaluate the flow system, contaminant transport, and attenuation processes resulting from reactions. The modeling and new data collection could also support optimization of the MNA portion of the remediation system by determining the true extent and mechanisms of attenuation and identifying hot spots or other areas where additional treatment is necessary.

\subsubsection{Suggestions Related to Optimizing Remediation}

Although the panel has not reviewed past remedial designs and performance, it suggests that future remediation designs should more fully incorporate the groundwater flow and contaminant transport processes occurring at the 100-D Area. This is best accomplished in a modeling framework in which the characterization approach and methods discussed in this report are combined with current contaminant distribution; potential chromium interactions with other solutes, aquifer sediments, and the river water are considered. Such modeling can then be used to identify preferred remediation schemes, while ongoing field data collection can provide feedback to improve model predictions. 
SGW-39305, Rev. 0

This page intentionally left blank. 


\subsection{REFERENCES}

Akindunni, F.F., R.W. Gillham, B. Jr., and T. Franz, 1995. "Modeling of Contaminant Movement Near Pumping Wells: Saturated-Unsaturated Flow with Particle Tracking," Ground Water, Vol. 33, No. 2, pp. 264-274.

Anderson, M.P., 2005. "Heat as a Groundwater Tracer," Ground Water, Vol. 43, pp. 951-961.

Benner, S.G., E.W. Smart, and J.N. Moore, 1995. "Metal behavior during surface-groundwater interaction, Silver Bow Creek, Montana." Environmental Science \& Technology, Vol .29, No.7, pp.1789-1795.

BHI-00778, 1995, Chromium in River Substrate Pore Water and Adjacent Groundwater: 100$D / D R$ Area, Hanford Site, Washington, prepared for the United States Department of Energy by Bechtel Hanford, Inc., page 3-4 and 5-2.

Buchman, M.F. 1999. NOAA Screening Quick Reference Tables, NOAA HAZMAT Report 991, prepared by Seattle WA, Coastal Protection Restoration Division, National Oceanic and Atmospheric Administration, 12 pages.

Butler, K.E., J.-C. Nadeau, R. Parrott and A. Daigle, 2004, "Delineating Recharge to a River Valley Aquifer by Riverine Seismic and EM Methods," J. Environmental and Engineering Geophysics, Vol. 9, pp.95-109.

Campbell, T.J., K. Hatfield, H. Klammler, M. Annable, and P.S.C. Rao, 2006, "Magnitude and Directional Measures of Water and Cr(VI) Fluxes by Passive Flux Meter," Environmental Science and Technology, Vol. 40, No. 20, pp. 6392-6397.

Carle, S. F., 1999, "TPROGS - Transition Probability Geostatistical Software, Version 2.1, User Manual," Hydrologic Sciences Graduate Group, University of California, Davis.

Carle, S. F. and G. E. Fogg, 1997, "Modeling Spatial Variability with One and Multidimensional Continuous-Lag Markov Chains," Mathematical Geology, Vol. 29, No. 7, pp. 891-918.

Conant Jr., B. 2001, "A PCE Plume Discharging to a River: Investigations of Flux, Geochemistry, And Biodegradation in the Streambed" Ph.D. Dissertation, Department of Earth Sciences, University of Waterloo.

Conant Jr., B. 2004, "Delineating and Quantifying Ground-Water Discharge Using Streambed Temperatures," Ground Water, Vol. 42, No. 2, 243-257.

Conant Jr., B., F.F. Akindunni, and R.W. Gillham, 1995. "Effect of Well-Screen Placement on Recovery of Vertically Stratified Contaminants," Ground Water, Vol. 33, No. 3, pp. 445457.

Dawe, M.R. and K.T.B. MacQuarrie, 2005, "Assessing Water Travel Times During Riverbank Filtration, in Bringing Groundwater Quality Research to the Watershed Scale," N.R. Thomson (ed), International Association of Hydrological Sciences Publication, Vol. 297, pp. $97-102$.

DOE/RL-2008-01, 2008, Hanford Site Groundwater Monitoring for Fiscal Year 2007, Prepared for the United States Department of Energy. 
Dresel, P.E., C.C. Ainsworth, N.P. Qafoku, C. Liu, J.P. McKinley, E.S. Ilton, J.S. Fruchter and J.L. Phillips, 2008, Geochemical Characterization of Chromate Contamination in the 100 Area Vadose Zone at the Hanford Site, PNNL-17674, prepared for the United States Department of Energy by Pacific Northwest National Laboratory.

Freeze, R.A. and J.A.Cherry, 1979, Groundwater, Prentice-Hall, Inc., Englewood Cliffs, New Jersey.

Frtiz, B., 2008, "Future Investigation of Chromium Flux through the Hyporheic Zone at 100-D", workshop presentation, Richland, Washington, April 2008.

Fritz and Arntzen, 2007, "Effect of Rapidly Changing River Stage on Uranium Flux Through the Hyporheic Zone," Ground Water, Vol. 45, No. 6, pp 753-760.

Haeni, F. P. 1996, "Use of Ground-Penetrating Radar and Continuous Seismic-Reflection Profiling on Surface-Water Bodies in Environmental and Engineering Studies," Journal of Environmental \& Engineering Geophysics, Vol.1, No.1, pp.27-35.

Healy, R.W., and A.D. Ronan, 1996, "Documentation of Computer Program VS2DH for Simulation of Energy Transport in Variably Saturated Porous Media," U.S. Geological Survey Water Resources Investigation Report 96-4230, pp.36.

http://wwwbrr.cr.usgs.gov/projects/GW_Unsat/vstwo-dimensionali1.2/index.htm,

Hellerich, L.A., M.A. Poneiera, N.P. Nikolaidis, B.F. Smets, G.M. Dobbs, 2003. “Attenuation of a Mixed Chromium and Chlorinated Ethene Ground Water Plume in Estuarine Influenced Glaciated Sediments," Ground Water Monitoring \& Remediation, Vol. 23, No. 3, pp. 7484.

Henderson, T., 1994, "Geochemical Reduction of Hexavalent Chromium in the Trinity Sand Aquifer," Ground Water, Vol. 32, No. 3, pp. 477-486.

ITRC DSP-5, 2007, Technical and Regulatory Guidance: Protocol for Use of Five Passive Diffusion Samplers to Sample for a Variety of Contaminants in Groundwater, prepared by the Interstate technology \& Regulatory Council Diffusion/Passive Sampler Team.

Kalbus, E., Schmidt, C., Bayer-Raich, M., Leschik, S., Reinstorf, F., Balcke, G.U., Schirmer, M., 2007, "New Methodology to Investigate Potential Contaminant Mass Fluxes at the Stream-Aquifer Interface by Combining Integral Pumping Tests and Streambed Temperatures," Environ. Pollut. Vol. 148, No.39, pp.808-816.

Lee, D.R. 1985, "Method for Locating Sediment Anomalies in Lakebeds that can be Caused by Groundwater Flow," Journal of Hydrology, Vol. 79, pp.187-193.

Lee, D. R., Geist, D. R., Saldi, K., Hartwig, D., and Cooper, T., 1997, "Locating Ground-Water Discharge in the Hanford Reach of the Columbia River," Chalk River, Atomic Energy of Canada, Ltd, Prepared for the U.S. Department of Energy under contract DE-AC0676RLO 1830, 1-37.

Lowery, C. S., J. F. Walker, R.J. Hunt, and M.P. Anderson, 2007, Identifying Spatial Variability of Groundwater Discharge in a Wetland Stream Using a Distributed Temperature Sensor, Water Resour. Res. 43, DOI:10.1029/2007WR006145. 
Mackay, D.M., R.D. Wilson, M.J. Brown, W.P. Ball, G. Xia, and D.P. Durfee, 2000, “A Controlled Field Evaluation of Continuous vs. Pulsed Pump-and-Treat Remediation of a VOC-Contaminated Aquifer; Site Characterization, Experimental Setup, and Overview of Results," Journal of Contaminant Hydrology, Vol. 41, No. 1-2, pp.81-131.

Nikolaidis, N.P., G.A. Robbins, M. Scherer, B. McAninch, G. Binkhorst, J. Asikainen, and S.L. Suib, 1994, "Vertical Distribution and Partitioning of Chromium in a Glaciofluvial Aquifer," Ground Water Monitoring \& Remediation, Vol.14, No.3, pp.150-159.

Peterson, R.E., R Mackley, R.O. Mahood, 2008, "Discharge of Hanford Site Groundwater to the Columbia River System," presentation to the Groundwater-Columbia River Interactions Technical Workshop, Richland, WA, April 16-18, 2008

Peterson, S, 2008, "Geohydrology and Contamination in Hanford's 100 Areas," presentation to the Groundwater-Columbia River Interactions Technical Workshop, Richland, WA, April 16-18, 2008.

Peterson, R.E., M.D. Williams, and G.W. Patton, 2008, "Perspective on the Hanford SiteColumbia River Systems," presentation from the Washington Hydrogeology Symmposium, Tacoma, WA, May 1-3, 2007.

Peterson, R.E. and M.P. Connelly. 2001. Zone of Interaction between Hanford Site Groundwater and Adjacent Columbia River Channel. PNNL-13674, October 2001. Pacific Northwest National Laboratory, Richland, Washington.

Pitkin, S.E., Cherry, J.A., Ingelton, R.A., and M. Broholm. 1999, "Field Demonstrations Using the Waterloo Ground Water Profiler," Ground Water Monitoring and Remediation, Vol. 19, No. 2, pp.122-131.

PNNL 16623. 2007. Hanford Site Environmental Surveillance Data Report for Calendar Year 2006. PNNL-16623 APP. 1, Pacific Northwest National Laboratory, Richland, WA. 2006 (from page 2-7and 3-5)

Selker J., N. van de Giesen, M. Westhoff, W. Luxemburg, and M. B. Parlange (2006a), Fiberoptics Opens Window On Stream Dynamics, Geophys. Res. Lett., 33, L24401, doi:10.1029/2006GL027979.

Selker, J., L. Luc Thevenaz., H. Huwald, A. Mallet, W. Luxemburg, N. van de Giesen, M. Stejskal, J.M. Zeman, M. Westhoff, and M. B. Parlange (2006b), Distributed fiber-optic temperature sensing for hydrologic systems, Water Resour. Res., 42, W12202, doi:10.1029/2006WR005326.

USGS Circular 1260, 2003, Heat as a Tool for Studying the Movement of Ground Water Near Streams, USGS Circular 1260, Reston, Virginia.

Su, G.W., J. Japerse, D. Seymour, and J. Constantz, 2004, "Estimation of Hydraulic Conductivity in an Alluvial System Using Temperature," Ground Water, Vol. 42, pp.890901.

Weissmann, G. S. and G. E. Fogg (1999), Multi-scale alluvial fan heterogeneity modeled with transition probability geostatistics in a sequence stratigraphic framework. Journal of Hydrology 226, no. 1-2: 48-65. 
USEPA, 2007a, "Monitored Natural Attenuation of Inorganic Contaminants in Ground Water: Volume 1 Technical Basis for Assessment," USEPA/600/R-07/139, October 2007.

USEPA, 2007b. "Monitored Natural Attenuation of Inorganic Contaminants in Ground Water: Volume 2 Assessment for Non- Radionuclides Including Arsenic, Cadmium, Chromium, Copper, Lead, Nickel, Nitrate, Perchlorate, And Selenium," USEPA/600/R-07/140, October 2007.

USEPA, 1999. OSWER Directive 9200.4-17P "Use of Monitored Natural Attenuation at Superfund," RCRA Corrective Action, and Underground Storage Tank Sites, dated April $21,1999$.

USEPA, USEPA/600/R-98/128, 1998, "Technical Protocol for Evaluating Natural Attenuation of Chlorinated Solvents in Ground Water," September 1998.

USGS 99-4212, 1999, Numerical Simulation of Vertical Ground-Water Flux of the Rio Grande from Ground-Water Temperature Profiles, Central New Mexico, U.S. Geological Survey Water-Resources Investigations Report, pp.34.

USGS 2337, 1989, Use of Temperature Profiles Beneath Streams to Determine Rates of Vertical Ground-Water Flow and Vertical Hydraulic Conductivity, USGS Water-Supply Paper, pp. 35.

Weissmann, G. S. and G. E. Fogg 1999, "Multi-Scale Alluvial Fan Heterogeneity Modeled with Transition Probability Geostatistics in a Sequence Stratigraphic Framework," Journal of Hydrology, Vol. 226, No. 1-2, pp. 48-65

Williams et al, 1999, Anoxic Plume Attenuation in a Fluctuating Water Table System: Impact of 100-D Area In Situ Redox Manipulation on Downgradient Dissolved Oxygen Concentrations.

Winters, S. L. and D.R. Lee, 1987, "In Situ Retardation of Trace Organics in Groundwater Discharge to a Sandy Stream Bed," Environmental Science \& Technology, Vol. 21, No. 12, pp.1182-1186.

Winter, T. C., J.W. LaBaugh and D.O. Rosenberry, 1988, “The Design and Use of a Hydraulic Potentiomanometer for Direct Measurement of Differences in Hydraulic Head Between Groundwater and Surface Water," Limnology and Oceanography, Vol. 33, No. 5, pp.1209-1214.

Woessner, W.W., 2000, "Stream and Fluvial Plain Ground Water Interactions: Rescaling Hydrogeologic Thought," Ground Water, Vol. 38, No. 3, pp. 423-429.

Yabusaki et al., 2008, Reactive Transport in a Dynamic Vadose Zone-Aquifer River System, presentation to the Groundwater-Columbia River Interactions Technical Workshop, Richland, Washington, April 16-18, 2008).(from page 2-14)

\section{Other Publications}

Conant Jr., B., 2000. Ground-Water Plume Behavior Near the Ground-Water/Surface Water Interface of a River, USEPA/542/R-00/007, Proceedings of the Ground-Water/SurfaceWater Interactions Workshop, Denver Colorado, pp. 23-30. 
Fleckenstein, J.H., R.G. Niswonger, and G.E. Fogg, 2005, "Stream-Aquifer Interactions, Geologic Heterogeneity, and Low Flow Management," GROUNDWATER, Special issue from conference, MODFLOW and More 2003: Understanding through Modeling, Golden, CO.

Greenberg, M.S., G.A. Burton Jr., and C.D. Rowland. 2002, "Optimizing Interpretation of In Situ Effects of Riverine Pollutants: Impact of Upwelling and Downwelling," Environmental Toxicology and Chemistry, Vol. 21, No. 2, pp.289-297.

Hsieh, P.A., Wingle, W.L., Healy, R.W. 2000, "VS2D-A Graphical Software Package for Simulating Fluid Flow and Solute or Energy Transport in Variably Saturated Media," USGS Water Resources Investigation Report, Vol. 99-4130, pp.16.

LaBolle, EM, G.E. Fogg, A.F.B. Tompson, 1996, "Random-Walk Simulation of Transport in Heterogeneous Porous Media: Local Mass-Conservation Problem", Water Resources Research, Vol. 32, Issue 3, pp. 583-594.

Lowery, C. S., J. F. Walker, R.J. Hunt, and M.P. Anderson, 2007, Identifying Spatial Variability of Groundwater Discharge in a Wetland Stream Using a Distributed Temperature Sensor, Water Resour. Res. 43, DOI:10.1029/2007WR006145.

Niswonger, R.G. 2006, “The Hydroecological Significance of Perched Groundwater Beneath Streams," Unpublished Ph.D. thesis. Hydrologic Sciences Graduate Group, University of California, Davis, 2006, pp. 171.

Stanford, J.A., and J.V. Ward. 1988, “The Hyporheic Habitat of River Ecosystems," Nature Vol. 335, pp. 64-66.

USEPA, 2008. ECO Update/ Ground Water Forum Issue Paper: Evaluating GroundWater/Surface-Water Transition Zones in Ecological Risk Assessments. USEPA-540-R06-072, July 2008 
SGW-39305, Rev. 0

This page intentionally left blank. 
SGW-39305, Rev. 0

APPENDIX A

A-i 
SGW-39305, Rev. 0

This page left intentionally blank

A-ii 
SGW-39305, Rev. 0

\title{
GROUNDWATER-COLUMBIA RIVER INTERACTIONS TECHNICAL WORKSHOP
}

\author{
1200 Jadwin Avenue \\ Room B-1 (basement) \\ Richland WA \\ April 16-18, 2008
}

\subsection{Wednesday, April 16}

9:00-9:15 Introductions, Objectives, and Logistics

Scott Petersen

$\begin{array}{ll}\text { 9:15-9:45 } & \text { Hanford Site Geology and } \\ & 100 \text { Area Chromium Plumes } \\ \text { 9:45-11:00 } & \text { Introduction to Field Trip } \\ \text { 11:00-12:30 } & \text { Badging and Pick Up Box Lunches } \\ \text { 12:30-5:00 } & \text { Site Tour }\end{array}$

Dawn Kaback

Scott Petersen

Bob Peterson

$12: 30-5: 00$

Site Tour

Panel

Panel

\subsection{Thursday, April 17}

8:00-8:10

Welcome and Introductions

Mike

Thompson

Scott Petersen

$8: 10-8: 20$

Objectives and Logistics

Scott Petersen

Dawn Kaback

8:20-8:45

Regulatory Framework for Remedial Decisions

USEPA \&

Ecology

$8: 45-9: 45$

Basic Concepts: Hanford Aquifer and Columbia River

9:45-10:00 Break

10:00-10:45 River Corridor Baseline Risk Assessment

Jill Thomson

10:45-11:15 Columbia River Substrate Habitat

Brett Tiller

11:15-12:00 Field Methods and Historical Database

Tim Hanrahan

12:00-1:00 Lunch

Brad Fritz

1:00-5:00 Internal Panel Discussions

On Own

Panel 


\subsection{Friday, April 18}

8:00-11:45 Internal Panel Discussions and Preparation of Outbrief Panel

11:45-1:00 Lunch On Own

1:00-2:30 Outbriefing Panel \&

Audience

\section{Experts:}

Dr. William Woessner, University of Montana

Dr. Kerry MacQuarrie, University of New Brunswick

Dr. Sorab Panday, Geomatrix Consultants

Dr. George Matanga, US Bureau of Reclamation

Dr. Rich Niswonger, US Geological Survey

Dr. Brewster Conant, University of Waterloo

Dr. Robert Peterson, Pacific Northwest National Laboratory, adjunct member

\section{Objectives for the Groundwater-Surface Water Interaction Workshop}

- Improve understanding of the interaction between groundwater and the Columbia River as it relates to selection and design of remediation systems for treatment of chromate in groundwater in the 100 Areas at Hanford

- Review and evaluate past and current data and data collection methods, data analysis techniques, assumptions, and groundwater transport and mixing mechanisms. Evaluate modeling work dealing with groundwater and surface water interaction.

o Evaluate the current groundwater-surface water monitoring network, including the following:

- aquifer tubes

- monitoring wells

- shoreline and river monitoring

o Evaluate the role of modeling

Provide recommendations on data collection and analyses techniques 
SGW-39305, Rev. 0

APPENDIX B

ATTENDEES LIST

B-i 
SGW-39305, Rev. 0

This page left intentionally blank 


\section{Groundwater Surface Water Interaction Workshop Attendees}

\section{April 16-18, 2008}

\begin{tabular}{|c|c|c|c|}
\hline Name & Organization & Phone & Email \\
\hline Dawn Kaback & Geomatrix & $303-534-8722$ & dkaback@geomatrix.com \\
\hline Scott W. Petersen & Fluor Hanford & $509-372-9126$ & Scott_W_Petersen@rl.gov \\
\hline K. Michael Thompson & $\mathrm{RL}$ & $509-373-0750$ & K-M-Mike_Thompson@rl.gov \\
\hline Steve Yabusaki & PNNL & $509-372-6095$ & yabusaki@pnl.gov \\
\hline Ted Repasky & CTUIR & $541-966-2412$ & TedRepasky@ctuir.com \\
\hline Sandra Lilligren & NezPerce & $208-843-7375$ & sandral@nezperce.org \\
\hline Stan Sobczyk & NPT-ERUM & $208-843-7375$ & stans@nezperce.org \\
\hline Jacqui Shea & Dept. of Ecology & $509-372-7925$ & jash461@ecy.wa.gov \\
\hline Blaine Rowley & DOE EM-20 & $301-903-2777$ & blaine.rowley@em.doe.gov \\
\hline Ron Jackson & $\mathrm{FH}$ & $509-373-3599$ & Ronald_L_Jackson@rl.gov \\
\hline Matt Tonkin & SSPA/Fluor & $508-815-9886$ & matt@sspa.com \\
\hline Brad Fritz & PNNL & $509-371-7119$ & Bradley.Fritz@pnl.gov \\
\hline Evan Arntzen & PNNL & $509-539-3457$ & Evan.arntzen@pnl.gov \\
\hline Tim Hanrahan & PNNL & $509-371-7182$ & Tim.hanrahan@pnl.gov \\
\hline Alicia Boyd & EPA & $509-376-4919$ & Boyd.alicia@EPA.gov \\
\hline Jim Hanson & DOE-RL & $509-373-9068$ & James_P_Hanson@rl.gov \\
\hline William Woessner & Univ of MT & $406-721-3590$ & William.Wossner@umontana.edu \\
\hline George Matanga & USBR & $916-978-5084$ & gmatanga@mp.usbr.gov \\
\hline Brewster Conant & Univ Waterloo & $519-746-9739$ & bconantj@uwaterloo.ca \\
\hline Kerry MacQuarrie & Univ New Brunswick & $506-453-5121$ & Ktm.unb.ca \\
\hline Sorab Panday & Geomatrix & $703-483-6468$ & spanday@geomatrix.com \\
\hline Rich Niswonger & USGS & $775-887-7727$ & rniswon@usgs.gov \\
\hline Barbara Harper & CTUIR & $541-966-2804$ & bharper@amerion.com \\
\hline John Gear & Oregon Energy & $543-378-5584$ & John.Gear@STATE.OR.US \\
\hline Rod Lobos & EPA & $509-576-3749$ & lobos.rod@EPA.gov \\
\hline Bob Peterson & PNNL & $509-371-7226$ & Robert.peterson@pnl.gov \\
\hline Greg Patton & PNNL & $509-371-7071$ & Gw.patton@pnl.gov \\
\hline **Dan Tyler & Freestone & $509-943-5222$ & dantyler@gofreestone.com \\
\hline **S.H. Hall & Freestone & $509-943-5222$ & stevehall@gofreestone.com \\
\hline **John Houck & Freestone & $509-943-5222$ & johnhouck@gofreestone.com \\
\hline **Erika Garcia & Freestone & $509-943-5222$ & erikarincon@gofreestone.com \\
\hline **Alisa Huckaby & Dept. of Ecology & $509-372-7909$ & ahuc461@ecy.wa.gov \\
\hline **Beth Rochette & Ecology & & Broc461@ecy.wa.gov \\
\hline **David S. Miller & Fluor & & David_S_Miller@rl.gov \\
\hline **Jay McConnaughey & Yakama National & $509-452-2502$ & Mccon.j@clearwire.net \\
\hline
\end{tabular}


SGW-39305, Rev. 0

\begin{tabular}{|l|l|l|l|}
\hline$* *$ Jane Borghese & Fluor & & Jane_V_Borghese@rl.gov \\
\hline **Craig Swanson & Fluor & & L_Craig_Swanson@rl.gov \\
\hline *Ann Shattuck & Fluor & $509-376-8750$ & Ann_f_shattuck@rl.gov \\
\hline
\end{tabular}

*April $16^{\text {th }}$ Attendance

** April $18^{\text {th }}$ Attendance 
SGW-39305, Rev. 0

APPENDIX C

EXPERT PANEL BIOGRAPHIES (TBD)

C-i 
SGW-39305, Rev. 0

This page left intentionally blank

C-ii 
Dr. Brewster Conant Jr. is a Research Assistant Professor in the Department of Earth and Environmental Sciences at the University of Waterloo and has more than 20 years of experience in hydrogeology and environmental consulting. He received a B.Sc. in GeologyPhysics/Mathematics from Brown University in 1984, and received a M.Sc. and Ph.D. in Earth Sciences at the University of Waterloo in 1991 and 2001, respectively. He has worked as both a geologist in the engineering consulting firm of Whitman and Howard Inc., and later as a senior hydrogeologist for the groundwater specialist firm of GeoTrans Inc. He has designed, managed, and conducted hydrogeological investigations for site assessments, water supply protection, landfill assessments, remediation, litigation, regulatory negotiation, and modeling studies. General areas of research interest include physical and contaminant hydrogeology and in field methods and instrumentation. His area of expertise is in interactions at the groundwater/surface water interface and the examination of flow, geochemical, and biodegradation processes affecting the fate and transport of contaminants passing through it. He has been an invited speaker at several scientific meetings and also at national meetings of the USEPA. He has cotaught training courses for the USEPA on the topic of ecological and hydrogeological issues related to groundwater/surface-water interactions.

Kerry MacQuarrie is a Professor of Civil Engineering and a Canada Research Chair in Groundwater-Surface Water Interactions at the University of New Brunswick (UNB). Dr. MacQuarrie is also a Fellow of the Canadian Rivers Institute and the Coordinator of the Groundwater Studies Group at UNB. Dr. MacQuarrie has served as a member of the Executive Committee of the Hydrogeology Division for the Canadian Geotechnical Society, the Expert Committee on Groundwater for the Council of Canadian Academies, and as an Associate Editor of the Journal of Hydrology. Dr. MacQuarrie holds a Bachelor of Science in Civil Engineering from the University of New Brunswick, and a Master of Science and a Ph.D. in Earth Sciences (Hydrogeology) from the University of Waterloo. He is a Registered Member of the Association of Professional Engineers and Geoscientists of New Brunswick.

Dr. MacQuarrie's research interests include the transport and fate of contaminants in the subsurface and the use of hydraulic, thermal, and geochemical information to understand groundwater-surface water interactions; riverbank filtration for safe drinking water supply; groundwater influences on cold-water fish habitat; groundwater-derived nitrogen loading to shallow estuaries; numerical modeling of groundwater flow and solute transport; and multicomponent reactive transport modeling.

George Bwalya Matanga received B.S., M.S. and Ph.D. degrees in Civil Engineering from, respectively, California State University at Sacramento, University of California at Berkeley and University of California at Davis. He undertook post-doctoral research in numerical modeling of groundwater flow and transport in Department of Earth Sciences, University of Waterloo, Canada. He has taught graduate courses and undertaken research in groundwater flow and transport modeling at University of California and Oregon State University. He has more than twenty-five years of experience in consulting firms and government agencies in United States, Canada and Germany. As a consultant to UNICEF, he provided advice to UNICEF South Africa on use of groundwater resources in water supply and sanitation, and training in groundwater hydrology and numerical modeling to South African professionals from government, industry, and academia. He is currently employed by the U.S. Bureau of Reclamation, assisting with 
application of a fully-coupled surface and subsurface numerical model, HydroGeoSphere, in Central Valley of California and Upper Klamath Basin.

Richard G Niswonger is a research hydrologist for the U.S. Geological Survey. He received his B.S. in Environmental Engineering from Humboldt State University, a M.S. in hydrogeology from the University of Nevada and a Ph.D. in hydrology from the University of California, Davis. His research concentrates on quantifying surface-water groundwater interactions in watersheds and alluvial basins; including interactions at lakes, wetlands and streams and the development and application of ground water flow models. He co-authored an integrated hydrologic model called GSFLOW, which was recently released by the USGS, and is being used to assess water resources and the effects of climate change in several basins across the country. He has published more than 20 professional papers, and has presented more than 30 professional talks.

Dr. Sorab Panday is recognized as a leader in his field, Dr. Panday brings 20 years of experience in water resource analysis and groundwater flow and transport modeling to address a variety of issues including conjunctive surface-water groundwater use and management; hydrogeologic and contaminant plume characterization; remediation, containment and persistence/attenuation analyses for dissolved contaminants, waste munitions, petroleum products, and volatile organics; radionuclide fate and transport; TMDL implementation; management operations for environmentally sensitive ecosystems; agricultural, industrial, mining and urbanization impacts on flow and water quality; impacts of climate and land use changes on flooding and groundwater recharge; saltwater intrusion in surface and subsurface systems; and water rights/permitting/litigation support. He has conducted and managed hundreds of projects of varying complexity, size and duration including model development and application; data, model and document reviews; and expert panel participation. Further, he has provided leadership to projects and staff; developed technical scope and workplans; provided technical training and guidance; conducted project organization, planning and staffing; handled personnel and technical issues; monitored schedule and cost of projects; and maintained effective communication with clients.

William W. Woessner is currently Chair of the Geosciences Department and a Regents' Professor of Hydrogeology at the University of Montana where he has been a faculty member since 1981 teaching classes in applied hydrogeology, advanced hydrogeology, ground water modeling, applied ground water modeling, surface water/ground water interaction, and ground water remediation. He received his B.A. in geology from the College of Wooster, a M.S. in geology from the University of Florida, a M.S. in water resources management and a Ph.D. in geology (hydrogeology and a minor in civil and environmental engineering) from the University of Wisconsin-Madison. .His research concentrates on quantifying flow systems in intermountain valleys; water resources systems analyses, including ground water/surface water interactions at lakes, wetlands and streams; characterization of hazardous wastes; and contaminant transport (including virus transport); and the development and application of groundwater flow and contaminant models. He co-authored with Mary P. Anderson the popular reference text Applied Groundwater Modeling, Simulation of Flow and Advective Transport (1992). He has published more than 60 professional papers, has presented more than 200 professional talks, and has served as the chair for more than 60 graduate students. 
SGW-39305, Rev. 0

APPENDIX D

TPROGS GEOSTATISTICAL MODELING OF HYDROFACIES

D-i 
SGW-39305, Rev. 0

This page left intentionally blank

D-ii 
TPROGS (Carle, 1999) is a geostatistical modeling package that can be used to represent heterogeneity in hydrofacies within the region of interest. The first step involves identification of geologic units, which in the Hanford Site case would include the Hanford and Ringold Formations within the 100 Areas.

Sediments within each geologic unit are first categorized into two or more hydrofacies based on geologic interpretation and sediment type and distribution. A set of hydraulic properties are assigned to each hydrofacies category, and thus, it is assumed that the hydrologic properties are homogeneous within a hydrofacies category. Heterogeneity within each unit (e.g. Hanford and Ringold Formations) is developed separately, because statistical stationarity is rarely present among different geologic units.

As an example, "Multi-Scale Alluvial Fan Heterogeneity Modeled with Transition Probability Geostatistics in a Sequence Stratigraphic Framework," (Weissmann and Fogg 1999) studied the King's River alluvial fan and categorized hydrofacies within a single geologic unit according to 1) mud that typically represents floodplain deposits, composed predominantly of silts and clays; 2) muddy sands comprised of silty and clayey sands and sandy silts and clays that characterize the transitional zone between channel and floodplain deposits; and 3) channel deposits made up of gravel and relatively clean sand. Similarly, the Hanford Formation could be categorized into 1) silty sand flood-plain material originating from the Upper Ringold Mud unit, 2) clean sand river deposits, and 3 ) coarse sand and gravel riverbed deposits. These categories could be refined using sediment size fractions analyzed from representative core samples, as well as using knowledge of the depositional processes for each of the geologic formations (e.g., cataclysmic flood deposits).

Hydraulic properties (i.e., hydraulic conductivity, storage capacity, and porosity) are then assigned to each hydrofacies based on values published in the literature for similar sediment types, or based on field experiments (e.g. slug tests), and/or laboratory analysis of sediment core samples representative of each texture category.

Statistical properties of the hydrofacies (hydrofacies mean lengths, global proportions, transition rates) are estimated using software called TPROGS to develop three-dimensional distributions of sediment heterogeneity. These statistical properties can be based on the lithological interpretation of the driller's logs, based on hydrofacies outcrops within the riverbanks, or grain size analyses from sediment cores.

To develop the TPROGS representation of heterogeneity, data input files that are compatible with TPROGS must be constructed. These data are used to develop transition probability matrices, which are fitted with Markov-chain models, as shown in Figure D. 1 for the Cosumnes River, CA. The character of the transition probabilities and fitted Markov-chain models provide information regarding trends in the sediment heterogeneity. For example, fluvial material can consist of sediment fining-upward series that results in a higher probability for a fine sand to lie on top of a coarse sand, rather than the reverse condition. The tendencies for a particular hydrofacies to be adjacent to another are often related to the physical processes that resulted in the development of a sediment sequence, such as a river first depositing coarse sand and gravel during peak flow followed by fine sand and silt as the flow subsides.

Typically, driller's logs provide sufficient information to calculate vertical transition rates for the development of a TPROGS model (vertical Markov-chain model); however, transition rates estimated for the horizontal directions are usually unreliable, because of an insufficient number 
of boreholes and insufficiently small borehole spacing relative to lateral variability. If insufficient data are available to characterize the horizontal directions, the approach of, "Modeling Spatial Variability with One and Multidimensional Continuous-Lag Markov Chains," Carle and Fogg 1997) can be used to develop transition probability matrices based on knowledge of the global hydrofacies proportions, estimated mean hydrofacies lengths, and hydrofacies juxtaposition tendencies. The statistical properties for the horizontal directions are likely especially important at the Hanford Site, because these properties reflect the connectivity of preferential flow paths that could transport chromium to the river. The quality of the data available for horizontal directions can be assessed by plotting the transition probabilities (example shown below) according to the TPROGS user's manual. Further instructions on this approach are provided by Carle (1999).

Because it is not practical to sample heterogeneity within the subsurface completely, there is uncertainty in the TPROGS models. Thus, a certain amount of the region is represented by random placement of hydrofacies categories within a region, which means that there are many equally probable manifestations of the heterogeneity (realizations). However, for applications that have sufficient data to develop robust transition probability matrices, predictions of groundwater flow and transport will be very similar among realizations of heterogeneity. Based on the number of wells with driller's log data for the 100-D Area, there is likely to be sufficient data available to build a realistic model of heterogeneity using TPROGS.

However, the groundwater flow and transport model should be run with different realizations of heterogeneity to assess the uncertainty in chromium flux to the river. Figure D.2 is an example of three realizations of heterogeneity developed for the Cosumnes River. It should be noted that the size of cell blocks that represent heterogeneity need to be smaller than the average lengths and thicknesses of the hydrofacies, Carle and Fogg (1997). It is most convenient to create the groundwater flow and transport model to have the same cell block size as those used in TPROGS. For this case, the hydraulic properties for each cell block within the groundwater model can be assigned based on the hydrofacies category in the corresponding TPROGS model. If the cell blocks for the groundwater model are larger than the blocks used for TPROGS then an averaging procedure must be employed.

\section{Recommendations:}

1. Compile all data related to the distribution of sediment types within the Hanford and Ringold Mud Units, including driller's logs and geologic interpretations.

2. Develop hydrofacies categories based on depositional processes and laboratory testing of representative core samples.

3. Develop three-dimensional hydrofacies models using TRPOGS or other geostatistical model.

4. Incorporate three-dimensional hydrofacies models into a groundwater flow and transport model to evaluate the effects of sediment heterogeneity on the transport of chromium in the subsurface.

Figure D.1 Vertical Markov-chain models fitted to measured transition probabilities for a three hydrofacies model for the Cosumnes River, CA 
SGW-39305, Rev. 0
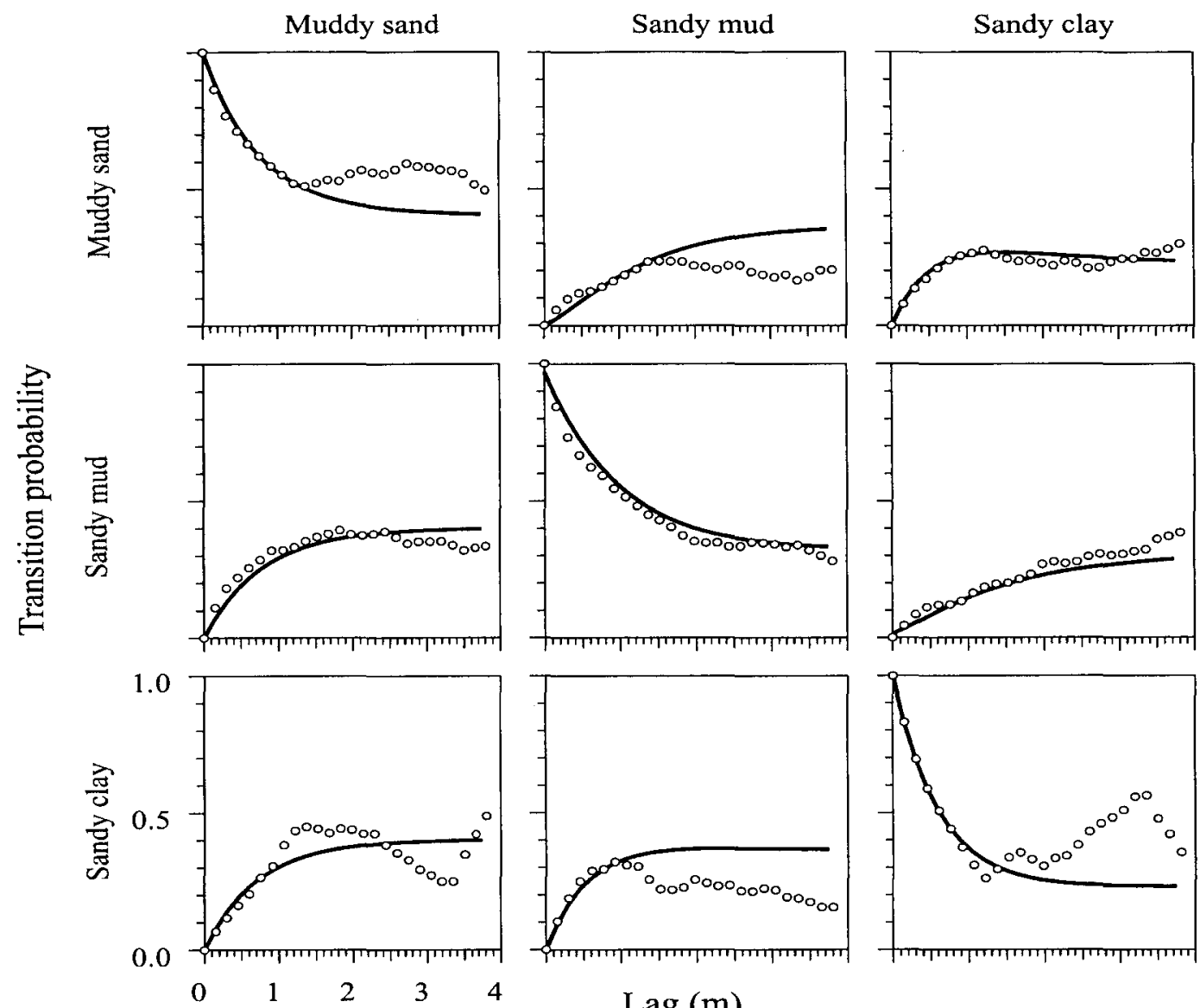

Measured

Lag (m)

- 000 .

Markov chain 


\section{SGW-39305, Rev. 0}

Figure D.2 Three-facies geostatistical realizations
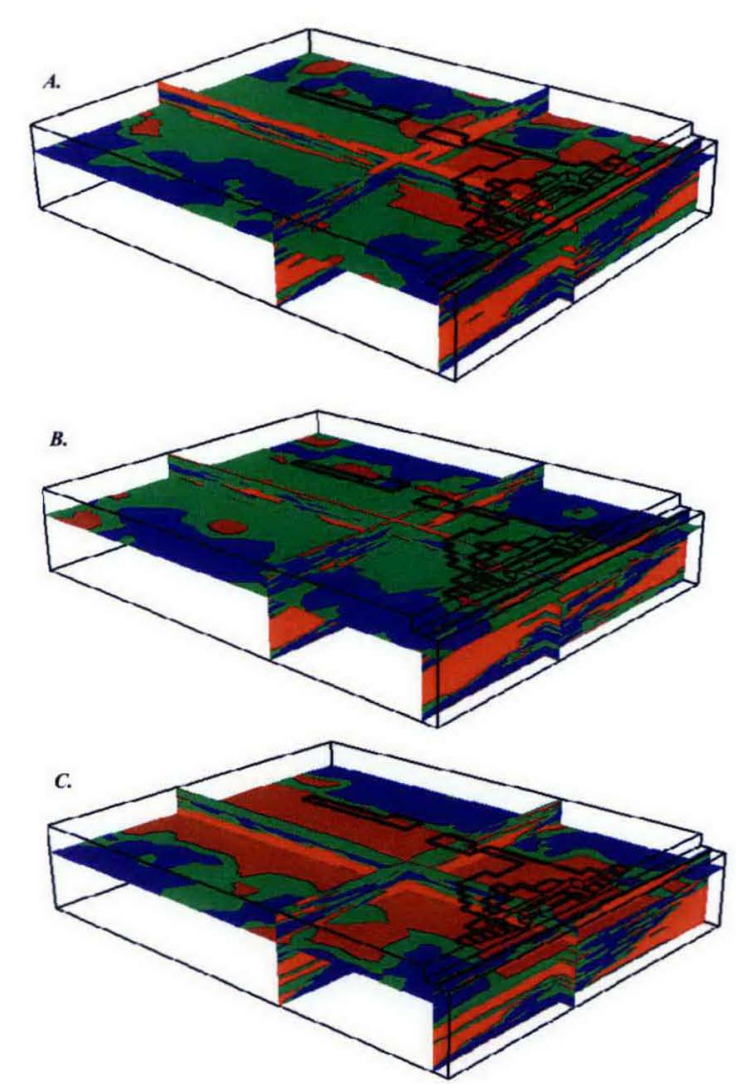

Red, green and blue colors represent the muddy sand, sandy mud, and sandy clay hydrofacies, respectively 